Published in final edited form as:

J Immunol Methods. 2007 September 30; 326(1-2): 93-115.

\title{
Loss of $\mathrm{T}$ cell responses following long-term cryopreservation
}

\author{
Rachel E. Owen ${ }^{a, b^{*}}$, Elizabeth Sinclairc ${ }^{c}$ Brinda Emuc ${ }^{c}$, John W. Heitman ${ }^{a}$, Dale F. \\ Hirschkom $^{\mathrm{a}}$, C. Lorrie Epling ${ }^{\mathrm{C}}$, Qi Xuan Tan ${ }^{\mathrm{C}}$, Brian Custer ${ }^{\mathrm{a}}$, Jeffery M. Harris ${ }^{\mathrm{d}}$, Mark A. \\ Jacobson ${ }^{\mathrm{C}}$, Joseph M. McCune ${ }^{\mathrm{C}}$, Jeffery N. Martin ${ }^{\mathrm{C}}$, Frederick M. Hecht ${ }^{\mathrm{C}}$, Steven G. \\ Deeks $^{\mathrm{C}}$, and Philip J. Norris $\mathrm{a}, \mathrm{b}, \mathrm{c}$ \\ aBlood Systems Research Institute, 270 Masonic Avenue, San Francisco, CA 94118, USA \\ bDepartment of Laboratory Medicine, University of California San Francisco, San Francisco, California, \\ USA \\ cDivision of Experimental Medicine, Department of Medicine, University of California San Francisco, San \\ Francisco, California, USA \\ $\mathrm{d}$ Gladstone Institute of Immunology and Virology/Department of Pediatrics, University of California San \\ Francisco, San Francisco, California, USA
}

\section{Abstract}

\begin{abstract}
Although cryopreservation of peripheral blood mononuclear cells (PBMC) is a commonly used technique, the degree to which it affects subsequent functional studies has not been well defined. Here we demonstrate that long-term cryopreservation has detrimental effects on T cell IFN- $\gamma$ responses in human immunodeficiency virus (HIV) infected individuals. Long-term cryopreservation caused marked decreases in $\mathrm{CD}^{+} \mathrm{T}$ cell responses to whole proteins (HIV p55 and cytomegalovirus (CMV) lysate) and HIV peptides, and more limited decreases in $\mathrm{CD} 8^{+} \mathrm{T}$ cell responses to whole proteins. These losses were more apparent in cells stored for greater than one year compared to less than six months. $\mathrm{CD} 8^{+} \mathrm{T}$ cell responses to peptides and peptide pools were well preserved. Loss of both $\mathrm{CD}^{+}$and $\mathrm{CD} 8^{+} \mathrm{T}$ cell responses to $\mathrm{CMV}$ peptide pools were minimal in HIV-negative individuals. Addition of exogenous antigen presenting cells (APC) did not restore $\mathrm{CD}^{+} \mathrm{T}$ cell responses to peptide stimulation and partially restored $\mathrm{T}$ cell IFN- $\gamma$ responses to $\mathrm{p} 55$ protein. Overnight resting of thawed cells did not restore T cell IFN- $\gamma$ responses to peptide or whole protein stimulation. A selective loss of phenotypically defined effector cells did not explain the decrement of responses, although cryopreservation did increase $\mathrm{CD} 4^{+} \mathrm{T}$ cell apoptosis, possibly contributing to the loss of responses. These data suggest that the impact of cryopreservation should be carefully considered in future vaccine and pathogenesis studies. In HIV-infected individuals short-term cryopreservation may be acceptable for measuring $\mathrm{CD}^{+}$and $\mathrm{CD} 8^{+} \mathrm{T}$ cell responses. Long-term cryopreservation, however, may lead to the loss of $\mathrm{CD}^{+} \mathrm{T}$ cell responses and mild skewing of $\mathrm{T}$ cell phenotypic marker expression.
\end{abstract}

\section{Keywords}

Cryopreservation; T cells; IFN- $\gamma$; HIV; Intracellular cytokine staining

\section{Introduction}

Cryopreservation of PBMC is a commonly used practice to preserve cells for future phenotypic and functional analyses in a wide range of infectious disease and vaccine studies. The

*Corresponding author. Blood Systems Research Institute, 270 Masonic Avenue, San Francisco, CA 94118, USA. Tel.: +1 415923 5774; fax: +1 415567 5899. E-mail address:rowen@bloodsystems.org (R.E. Owen). 
availability of large repositories of banked specimens allows multi-center studies to be performed by batch testing, avoiding some of the issues of assay variability that are introduced by testing independently isolated fresh samples. In the context of HIV vaccine and pathogenesis studies, repositories of banked frozen PBMC samples allow retrospective monitoring of cellular immune responses by ex vivo assays such as ELISPOT and intracellular cytokine staining. Accurate quantitation of cellular immune responses is important in such studies because these responses are thought to play an essential role in control of viral replication (Borrow et al., 1994;Rosenberg et al., 1997;Altfeld et al., 2001;McMichael and RowlandJones, 2001). Also, the design of most active phase II/III vaccine studies is to bank cells from all participants and to retrospectively use these cells to define the immunologic correlates of viral control. A precise and rigorous appreciation of the impact of cryopreservation is required to interpret the results of such studies.

While cryopreservation is a useful tool, it is a harsh process for cells to undergo. To prevent lethal ice crystal formation in frozen cells, $10 \%$ dimethyl sulphoxide (DMSO), a polar aprotic solvent, is commonly added to fetal bovine serum (FBS) to create a cryoprotectant freezing solution. DMSO at such concentrations is toxic to cells. The risk of damage to cells from the freezing and thawing process is high and may result in alterations to the phenotype and function of cells (Tollerud et al., 1991;Romeu et al., 1992;Rosillo et al., 1995;Koenigsmann et al., 1998;Hattori et al., 2001;Cavers et al., 2002;Costantini et al., 2003). The lethality of intermediate temperatures during cooling and thawing are particularly problematic (Gao and Critser, 2000), and research groups have optimized freezing and storage conditions to offer preservation of cell viability (Kreher et al., 2003; Disis et al., 2006;Smith et al., 2007). Studies assessing the effects of freezing and thawing on PBMC have found minimal effects on the viability of cells (Birkeland, 1980; Sobota et al., 1997; Hayes et al., 2002), with no significant difference between fresh and frozen cell responses to recall antigens (Kreher et al., 2003; Maecker et al., 2005;Disis et al., 2006). Weinberg et al. (2000) and Reimann et al. (2000) found the function of eryopreserved PBMC in lymphoproliferative assays was associated with cell viability. Other investigators have also measured an improvement of responses in frozen samples versus freshly isolated PBMC (Weinberg et al., 1998;Maecker et al., 2005). However, there are also reports of reduced function assessed by lymphoproliferative assays to select recall antigens such as HIV p24 and CMV, and to mitogens in frozen PBMC compared to freshly isolated PBMC (Costantini et al., 2003; Miniscalco et al., 2003). The reason for these inconsistent observations has not been well defined. Two recent studies show that the time elapsed between phlebotomy and cryopreservation can result in lower functional responses (Bull et al., 2007; Kierstead et al., 2007). Other factors may include the quality of the cryopreservation and storing procedures (which are generally not standardized), as well as the duration of cryopreservation. Of note, most studies comparing fresh and frozen responses have used relatively short-term sample storage in liquid nitrogen (a few weeks to a few months), and the effect of long-term cryopreservation on the function of PBMC has not been fully investigated.

During our studies of HIV-specific immune responses, we noted a loss of responses in frozen specimens compared to initial responses measured with freshly isolated PBMC or cells eryopreserved for a short time period. Given these observations, we more formally characterized the effect of cryopreservation on $\mathrm{CD} 4^{+}$and $\mathrm{CD} 8^{+} \mathrm{T}$ cell IFN- $\gamma$ responses to both peptides and proteins. In two independent laboratories we assessed the effects of cryopreservation on samples obtained from acutely and chronically HIV infected individuals and from HIV uninfected individuals. To determine if the effect of cryopreservation was limited to HIV-specific responses or was more broadly defined, we also measured responses to CMV peptides or lysate and to a superantigen. Finally, we conducted a series of mechanistic studies to define why responses may change during cryopreservation. Specifically, we performed add- 
back studies using autologous B-lymphoblastoid cell lines (B-LCL) as a source of exogenous $\mathrm{APC}$ and measured the proportion of apoptotic cells before and after antigenic stimulation.

\section{Materials and methods}

\subsection{Study subjects}

Blood samples were obtained after informed consent from HIV-infected individuals enrolled in the University of California, San Francisco (UCSF) SCOPE (chronic HIV infection) and Options (acute HIV infection) cohorts, from donors who were enrolled in a study of structured treatment interruption (STI), from healthy donors who were HIV seronegative and CMV seropositive, and from HIV seronegative recipients of the Towne CMV vaccine. All samples were collected under protocols approved by the UCSF Committee on Human Research. Participants from SCOPE were selected based on a history of strong HIV-specific CD4 ${ }^{+} \mathrm{T}$ cell IFN- $\gamma$ secretion (Emu et al., 2005), including those in three categories: (1) long-term nonprogressor (LTNP) who have been infected at least 10 years with a viral load <5000 RNA copies/ml without antiretroviral therapy, (2) "elite" controllers who have an undetectable viral load ( $<75 \mathrm{RNA}$ copies $/ \mathrm{ml}$ ) without antiretroviral therapy, and (3) progressors who have higher viral loads ( $>10,000$ RNA copies $/ \mathrm{ml}$ ) and CD4 counts $<500$ cells $/ \mathrm{ml}$. Participants selected from the Options cohort were in primary HIV infection, determined by a negative HIV antibody or detuned antibody test (Janssen et al., 1998), a high viral load and a normal CD4 count, and were within 12-50 days from the onset of symptoms at their screening visit. STI subjects with a range of $\mathrm{CD}^{+} \mathrm{T}$ cell responses to Gag, Towne CMV vaccine recipients and healthy uninfected donors with a range of responses to CMV pp65 were selected. Characteristics of individual study subjects are summarized in Table 1.

\subsection{PBMC isolation and cryopreservation}

Blood drawn from SCOPE and Options individuals was collected in evacuated blood tubes (Vacutainer, Becton Dickinson, San Jose, CA) containing acid-citrate-dextrose. Blood drawn from Towne CMV vaccine recipients, individuals within the STI cohort and healthy HIV CMV-seropositive donors was collected in evacuated blood tubes containing heparin (Vacutainer, Becton Dickinson). Blood was separated on lymphoprep gradients (Accurate Chemical \& Scientific Corp., Westbury, NY) at Blood Systems Research Institute (BSRI) and on Ficoll Histopaque-1077 (Sigma-Aldrich, Saint Louis, MO) at UCSF Core Immunology Laboratory (CIL) and AIDS Specimen Bank (ASB), according to standard methods (Coligan, 2007). Fresh PBMC were stimulated as described below.

PBMC processed at BSRI were frozen in 10\% DMSO (Fisher Bioreagents, Fair Lawn, NJ), 65\% FBS, (HyClone, Logan, UT) and 25\% RPMI (UCSF Cell Culture Facility, San Francisco, $\mathrm{CA})$ at a concentration of 5-10 million cells per $\mathrm{ml}$ in $1 \mathrm{ml}$ aliquots. PBMC were frozen in 1 ${ }^{\circ} \mathrm{C}$ cyro "Mr. Frosty" freezing containers (VWR, West Chester, PA) to allow a controlled rate of freezing to $-80^{\circ} \mathrm{C}$ for $24 \mathrm{~h}$ prior to transfer into liquid nitrogen storage in the vapor phase at $-135^{\circ} \mathrm{C}$. Liquid nitrogen storage freezers were connected to an automatic fill system and an external alarm system to alert in the case of temperature failure.

Samples from individuals in the STI cohort, Towne CMV vaccine recipients and healthy

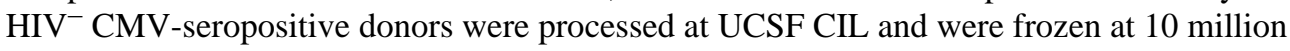
cells per $\mathrm{ml}$ in 10\% DMSO and 90\% FBS in $1 \mathrm{ml}$ aliquots. Controlled rate "Mr. Frosty" freezing containers were used at $-80^{\circ} \mathrm{C}$, prior to transfer into vapor phase liquid nitrogen storage tanks at $-135^{\circ} \mathrm{C}$ within $24 \mathrm{~h}$ of freezing. Liquid nitrogen freezers were manually filled, with levels checked and documented several times per week. 
Samples processed at UCSF ASB were frozen in ice cold 10\% DMSO and 90\% FCS at 10 million cells per $\mathrm{ml}$ in $1 \mathrm{ml}$ aliquots. Controlled rate freezing containers were used at $-70{ }^{\circ} \mathrm{C}$ for 4-24 h prior to transfer into vapor phase liquid nitrogen freezers at $-135^{\circ} \mathrm{C}$ for long-term storage. Liquid nitrogen storage freezers were connected to an automatic fill system and a wireless scanning system to alert in the event of temperature changes. The ASB undergoes extensive internal and external quality control monitoring and has consistently exceeded minimal requirements in terms of cell viability and other outcome measures. For example, the ASB participates in the Adult AIDS Clinical Trials Group Immunology Quality Assessment (IQA) program, and quarterly shipments of PBMC are sent to the IQA for viability and cell yield monitoring.

Specimens stored in liquid nitrogen for 0-170 days are defined as short-term cryopreserved, and specimens stored for 300 days or longer are defined as long-term cryopreserved.

\subsection{Thawing PBMC}

Cryopreserved PBMC were rapidly thawed in a $37^{\circ} \mathrm{C}$ water bath until only an ice chip remained and then added drop-wise into $10 \mathrm{ml}$ of culture media at $37^{\circ} \mathrm{C}$. Cells were washed and resuspended in an appropriate volume of culture media and counted using trypan blue dye exclusion (Sigma-Aldrich) or by Viacount on a Guava Personal Cell Analyzer (Guava, Hayward, CA). Cells were used directly after thawing or rested overnight in 1-2 $\mathrm{ml}$ of culture media in $15 \mathrm{ml}$ conical tubes (Falcon, Becton Dickinson Labwear, Franklin Lakes, NJ) loosely capped in a $5^{\circ}$ slant rack. Following resting, cells were washed in culture media and re-counted prior to stimulation.

\subsection{Antigens}

Peptides (15 amino acids long with an 11 amino acid overlap) spanning the entire HIV-1 consensus subtype B proteome (NIH AIDS Research \& Reference Reagent Program, Rockville, MD) were resuspended to $1 \mathrm{mg} / \mathrm{ml}$ stock solutions consisting of $90 \%$ purified water (Sigma-Aldrich) and 10\% DMSO (Fisher Bioreagents). The final concentration of each peptide used in the assays was $5 \mu \mathrm{g} / \mathrm{ml}$. Staphylococcal enterotoxin B (SEB; Sigma-Aldrich) was used as a positive control at a final concentration of $200 \mathrm{ng} / \mathrm{ml}$. CMV lysate (Microbix Biosystems Inc., Toronto, ON) was used at $5.86 \mu \mathrm{g} / \mathrm{ml}$. HIV-1 IIIB PR55 Gag (p55 protein; NIH AIDS Research \& Reference Reagent Program, Germantown, MD) was used at a final concentration of $5 \mu \mathrm{g} / \mathrm{ml}$. HIV-1 (MN) CL.4/CEMX174 (kind gift of J. D. Lifson, AIDS Vaccine Program, NCI, Frederick, MD) was used at a final concentration of capsid at $0.1075 \mu \mathrm{g} / \mathrm{ml}$. Peptide pools consisting of 15 amino acid long peptides with an 11 amino acid overlap corresponding to HIV Gag HXB2 (122 peptides; p55 peptide pool) and CMV pp65 matrix protein (138 peptides; CMV pp65 peptide pool) were used to stimulate paired whole blood and frozen PBMC samples. Final concentrations of $2 \mu \mathrm{g} / \mathrm{ml}$ of each peptide were used in whole blood and PBMC assays. Peptide pools were the kind gift of BD Biosciences (San Jose, CA).

\subsection{Stimulation of whole blood}

At UCSF CIL, one $\mathrm{ml}$ of fresh whole blood was stimulated with CMV pp65 and Gag p55 peptide pools. Purified anti-CD28/CD49d ( $1 \mu \mathrm{g} / \mathrm{ml}$ of each, BD Biosciences) was included for co-stimulation. For the negative control only co-stimulatory antibodies were added. After $2 \mathrm{~h}$ at $37^{\circ} \mathrm{C}$, Brefeldin A (Sigma-Aldrich) was added at a concentration of $10 \mu \mathrm{g} / \mathrm{ml}$, and the cells were incubated for an additional $4 \mathrm{~h}$ at $37^{\circ} \mathrm{C}$, then held at $18^{\circ} \mathrm{C}$ overnight. Cells were then washed, FACS Lysing Solution (BD Biosciences) was added to remove red blood cells, and cells were permeabilized with FACS Permeabilizing Solution (BD Biosciences). Cells were stained with the four-color panel described below. 


\subsection{Stimulation of PBMC}

At BSRI 1 million PBMC were suspended in $250 \mu$ l of either R10HS media, consisting of RPMI supplemented with $10 \%$ human AB serum (Sigma-Aldrich), $10 \mathrm{mM}$ Hepes (UCSF Cell Culture Facility) and $50 \mathrm{IU} / \mathrm{ml}$ penicillin/streptomycin (UCSF Cell Culture Facility) or in R20 media, consisting of RPMI supplemented with $20 \%$ FBS, $10 \mathrm{mM}$ Hepes and $50 \mathrm{IU} / \mathrm{ml}$ penicillin/streptomycin. Cells were stimulated for $2 \mathrm{~h}$ with antigens plus $1 \mu 1$ of purified antiCD28/CD49d (BD Biosciences) in 12×75 mm polystyrene tubes (Falcon, Becton Dickinson Labwear) prior to the addition of $10 \mu \mathrm{g} / \mathrm{ml}$ Brefeldin A (Sigma-Aldrich), and cells were cultured overnight in a $5^{\circ}$ slant rack at $37^{\circ} \mathrm{C}, 5 \% \mathrm{CO}_{2}$. For the negative control only costimulatory molecules were added. Co-stimulatory molecules were not added to samples that were to be stained with the eight-color apoptosis and phenotypic flow cytometry panel. Cells from SCOPE were stained with the three-color panel, and cells from Options were stained with the eight-color apoptosis and phenotypic flow cytometry panel described below.

Stimulation with CMV pp65 and Gag p55 peptide pools was performed at UCSF CIL in 96 well plates in the presence of $0.5 \mathrm{mg} / \mathrm{ml}$ Brefeldin A and co-stimulation as described above. Cells were stimulated for $6 \mathrm{~h}$ at $37^{\circ} \mathrm{C}$ in a temperature-controlled plate incubator (INHECO, Munich, Germany) and held at $18{ }^{\circ} \mathrm{C}$ after the incubation period. Cells were stained at UCSF CIL with the six-color panel described below.

\subsection{Antibodies and flow cytometry}

Unless otherwise noted, all antibodies were obtained from BD Biosciences or BD Pharmingen. Antibodies to the following markers were used in the BSRI laboratory: a three-color panel for analysis of PBMC responses consisted of CD3-FITC, CD4-PE and IFN- $\gamma$-APC; an eight-color panel to assess responses, $\mathrm{T}$ cell phenotype and apoptosis consisted of CD3-Pacific Blue, CD4Alexa Fluor 700, CD45RA-PE-Cy7, CD28-PerCPCy5.5, CD14-Tri-Color (Caltag, Carlesbad, CA), CD16-PE-Cy5, CD19-PE-Cy5, CCR7-PE, activated caspase-3-FITC and IFN- $\gamma$-APC. Ethidium monoazide (EMA; Invitrogen-Molecular Probes, Carlsbad, CA) was used at $0.2 \mu \mathrm{g} /$ $\mathrm{ml}$ in the apoptosis and phenotypic panel as a viability stain.

At UCSF CIL, a four-color panel used for analysis of whole blood responses consisted of IFN$\gamma$-FITC, CD3-APC, CD69-PE and CD4-PE-Cy5 (Beckman Coulter Inc., Fullerton, CA). A six-color panel for PBMC analysis consisted of CD8-ECD (Beckman Coulter Inc.), CD4-APC, CD3-Pacific Blue, IFN- $\gamma$-FITC, IL-2 PE and Aqua amine reactive dye (AARD; InvitrogenMolecular Probes, used as recommended by the manufacturer with an additional 1/2 dilution) as a viability dye.

Compensation controls included comp beads (BD Biosciences) stained with an equivalent volume of the test antibody, calibrite beads (BD Biosciences), and unstained cells.

Fluorescence minus one (FMO) controls were used to verify gating and compensation for eightcolor panel staining.

PBMC stimulated overnight at BSRI were washed in calcium and magnesium-free PBS (UCSF Cell Culture Facility) before surface staining for $20 \mathrm{~min}$ at $4{ }^{\circ} \mathrm{C}$ for the three-color panel. PBMC stained with the apoptosis and phenotypic panel were surface stained for $10 \mathrm{~min}$ at room temperature in darkness before a 10-minute exposure to bright light to activate EMA. Cells were washed in PBS and fixed with $100 \mu \mathrm{l}$ of Fixation reagent A (Caltag) for $10 \mathrm{~min}$ at room temperature. Cells were then washed and simultaneously permeabilized and stained with 100 ${ }^{3} 1$ of Permeabilization reagent B (Caltag) and IFN- $\gamma$-APC (for three-color analysis) for $30 \mathrm{~min}$ at $4{ }^{\circ} \mathrm{C}$. PBMC stained with the apoptosis and phenotypic panel were stained intracellularly with CD3-Pacific Blue, CCR7-PE, IFN- $\gamma$-APC and caspase-3-FITC for $20 \mathrm{~min}$ at room 
temperature in the dark. Cells were washed and resuspended in either $250 \mu 1$ of $1 \%$ paraformaldehyde (Sigma-Aldrich), or 1\% formaldehyde (JT Baker, Phillipsburg, NJ).

At UCSF CIL both whole blood and PBMC were treated with $2 \mathrm{mmol} / \mathrm{L}$ EDTA, and PBMC were washed and resuspended in PBS without protein prior to staining with AARD for 20 min. Antibody staining for both whole blood and PBMC was performed intracellularly for $50 \mathrm{~min}$ at room temperature following 10-minute incubations in FACS Lysing Solution followed by FACS Permeabilizing Solution (BD Biosciences). After staining, cells were washed and fixed in $0.5 \%$ paraformaldehyde. Whole blood samples were acquired on a FACSCalibur flow eytometer (BD Bioscience) using CellQuest software and an Autoloader with Worklist manager software (BD Biosciences). PBMC samples were collected on an LSRII flow eytometer (BD Biosciences). All data analysis was performed with FlowJo software (TreeStar, San Carlos, CA).

\subsection{PBMC and autologous $B-L C L$ co-culture}

PBMC $\left(5 \times 10^{6}\right)$ were transformed with $1 \mathrm{ml}$ Epstein Barr Virus (EBV) supernatant harvested from the B95-8 cell line (American Type Culture Collection, Manassas, VA), $0.1 \mu \mathrm{g} / \mathrm{ml}$ cyclosporin A (Sigma-Aldrich) and $0.5 \mu \mathrm{g} / \mathrm{ml}$ phytohemagglutinin (PHA; Sigma-Aldrich) in R20 culture media. Following successful transformation, B cell cultures were maintained in R20. For PBMC stimulation assays $5 \times 10^{5}$ autologous B-LCL were pre-pulsed with $2 \times$ final concentration of antigen in $125 \mu \mathrm{R} 10 \mathrm{HS}$ in $12 \times 75 \mathrm{~mm}$ polystyrene tubes for $1 \mathrm{~h}$. PBMC $\left(5 \times 10^{5}\right)$ were added to the B-LCL in a $125 \mu \mathrm{l}$ volume of R10HS and co-cultured for $2 \mathrm{~h}$ in a $5^{\circ}$ slant rack at $37^{\circ} \mathrm{C}, 5 \% \mathrm{CO}_{2}$. Cells were stimulated and stained for flow cytometric analysis using the three-color panel described above.

\subsection{Statistical analyses}

Short-term cryopreserved or fresh PBMC responses were compared to long-term cryopreserved PBMC responses by two-tailed, paired $t$ tests. Correlation of responses from fresh or short-term cryopreserved cells with long-term cryopreserved cells was measured by Spearman's correlation. Statistical analyses were performed with Stata 9.2 SE software (Stata Corp., College Station, TX). Bland-Altman analysis was performed with Prism 4.0c software (GraphPad Software, San Diego, CA).

\section{Results}

\subsection{Loss of responses in long-term cryopreserved PBMC}

We measured the $\mathrm{CD}^{+}$and $\mathrm{CD}^{+} \mathrm{T}$ cell IFN- $\gamma$ responses in fresh PBMC or cells isolated from individuals with chronic and acute HIV infection that were frozen short-term (0-170 days) or long-term (300 days or longer). The viability of the cells thawed immediately after long-term cryopreservation was $94 \%$ (range $88-99 \%$ ), with no difference in viability of cells processed and frozen at BSRI or at UCSF ASB either when studied immediately post-thawing or after resting (Table 2).

A loss of $\mathrm{CD} 4^{+} \mathrm{T}$ cell IFN- $\gamma$ responses to HIV whole Gag protein (p55 protein) was observed in long-term cryopreserved PBMC ( $t$ test, $p=0.023$ ) compared to freshly isolated PBMC from acute HIV infection and short-term cryopreserved PBMC from chronic HIV infection (Fig. 1a). There was no correlation between the responses measured in fresh or short-term and longterm cryopreserved PBMC (Spearman's Rho $=-0.06$ ) (Table 3). In an independent experiment the $\mathrm{p} 55$ protein was tested using $\mathrm{Gag}$-specific $\mathrm{CD} 4^{+} \mathrm{T}$ cell clones and was found to have preserved antigenicity (data not shown), implying that the loss of responses was not due to degraded 555 protein. There was a small gain of $0.069 \%(p=0.806)$ in $\mathrm{CD} 4^{+}$IFN- $\gamma$ responses to MN stimulation; however, there was no correlation between short-term cryopreserved and 
long-term cryopreserved PBMC responses (Spearman's Rho $=-0.09$ ). Finally, there was a trend towards the loss of $\mathrm{CD}^{+} \mathrm{T}$ cell IFN- $\gamma$ responses to individual HIV peptides. However, this did not reach statistical significance, possibly due to the small number of individuals tested from the chronic HIV cohort.

A statistically significant loss of $\mathrm{CD} 4^{+} \mathrm{T}$ cell IFN- $\gamma$ responses to CMV lysate in long-term cryopreserved PBMC compared to freshly isolated PBMC ( $t$ test, $p=0.038$ ) was also observed (Fig. 1a) in the acute HIV infection group (individuals from the chronic HIV cohort were not tested for responses to CMV lysate). In contrast, $\mathrm{CD}^{+} \mathrm{T}$ cell IFN $-\gamma$ responses to SEB were more robust and appeared to be maintained following long-term cryopreservation. The mean absolute decrease in the percentage of responding $\mathrm{CD}^{+} \mathrm{T}$ cells was $0.29 \%(p=0.023)$ to $\mathrm{p} 55$ protein stimulation, $0.87 \%(p=0.105)$ to HIV peptide stimulation, and $0.59 \%(p=0.038)$ to CMV lysate stimulation, demonstrating loss of responses to both whole protein and peptide antigens.

$\mathrm{CD}^{+} \mathrm{T}$ cell IFN- $\gamma$ responses to individual HIV peptides (Spearman's Rho $=0.88$ ) were maintained in PBMC following long-term cryopreservation, whilst CD8 ${ }^{+} \mathrm{T}$ cell IFN- $\gamma$ responses to whole protein antigens were lower in long-term cryopreserved PBMC and did not correlate with responses from freshly isolated or short-term cryopreserved PBMC (Table 3). $\mathrm{CD} 8^{+} \mathrm{T}$ cell IFN- $\gamma$ responses to SEB by long-term cryopreserved PBMC had a poor correlation to responses measured in freshly isolated or short-term cryopreserved PBMC (Spearman's Rho $=0.28$ ). Statistically significant reductions were observed between the freshly isolated or shortterm cryopreserved PBMC and long-term cryopreserved PBMC following p55 protein $(t$ test, $p=0.004$ ) and CMV lysate ( $t$ test, $p=0.041$ ) stimulation (Fig. 1b). The mean absolute decrease in the percentage of responding $\mathrm{CD} 8^{+} \mathrm{T}$ cells was $1.348 \%(p=0.004)$ to $\mathrm{p} 55$ protein stimulation, $0.281 \%$ ( $p=0.502)$ to HIV peptide stimulation, $0.254 \%(p=0.187)$ to $\mathrm{MN}$ stimulation and $1.637 \%$ ( $p=0.041$ ) to CMV lysate stimulation, reflecting a relatively greater loss of responses to the CMV and p55 whole protein antigens than to individual HIV peptides.

\subsection{Loss of $\mathrm{CD}^{+} \mathrm{T}$ cell responses confirmed in a second laboratory and specimen bank}

In a second series of independent experiments performed at UCSF CIL, T cell IFN- $\gamma$ responses to Gag p55 and CMV pp65 peptide pools were measured in PBMC that had been cryopreserved and in fresh whole blood, both in HIV-seropositive $\left(\mathrm{HIV}^{+}\right)$and HIV-seronegative (HIV ${ }^{-}$) individuals. A dramatic reduction in the $\mathrm{CD}^{+} \mathrm{T}$ cell IFN- $\gamma$ responses to the Gag p55 peptide pool was observed in PBMC cryopreserved for 2 to 5 years (Fig. 2a; $t$ test, $p=0.043$, Spearman's Rho=0.57). Responses to the CMV pp65 peptide pool in the same individuals were not statistically different $(t$ test, $p=0.645$ ) and correlated well with fresh responses (Table 3; Spearman's Rho $=0.96)$. In contrast to $\mathrm{CD} 4^{+} \mathrm{T}$ cells, $\mathrm{CD} 8^{+} \mathrm{T}$ cell IFN- $\gamma$ responses after longterm cryopreservation were preserved to both Gag p55 (Spearman's Rho=0.89) and CMV pp65 (Spearman's Rho=0.89) peptide pools (Fig. 2b).

$\mathrm{HIV}^{-}$individuals maintained their $\mathrm{CD} 4^{+}$and $\mathrm{CD} 8^{+} \mathrm{T}$ cell $\mathrm{IFN}-\gamma$ responses to $\mathrm{CMV}$ pp65 following long-term cryopreservation (Fig. 2a and b). Small decreases in the $\mathrm{CD}^{+} \mathrm{T}$ cell response to CMV pp65 were measured in the $\mathrm{HIV}^{-}$group (mean absolute decrease in the percentage of responding cells was $0.058 \%$ ), which were statistically significant in a two-tailed, paired $t$ test (Table 3). However, the mean absolute decrease in the percentage of responding cells was low $(0.058 \%)$ and Spearman's correlation coefficient was excellent $(\mathrm{Rho}=0.99)$ despite these small decreases. $\mathrm{HIV}^{+}$individuals also maintained their $\mathrm{CD}^{+} \mathrm{T}$ cell response to CMV pp65, with a mean gain of $0.307 \%$ in response. In contrast, the $\mathrm{CD}^{+} \mathrm{T}$ cell IFN- $\gamma$ response to the 555 peptide pool by long-term cryopreserved $\mathrm{PBMC}$ from $\mathrm{HIV}^{+}$individuals showed a mean loss of $0.363 \%$. Long-term cryopreserved PBMC from $\mathrm{HIV}^{-}$and $\mathrm{HIV}^{+}$ individuals maintained their $\mathrm{CD} 8^{+} \mathrm{T}$ cell IFN- $\gamma$ response to peptide pools (Fig. 2b). 
These results confirm the marked decline of $\mathrm{CD}^{+} \mathrm{T}$ cell responses and the preservation of $\mathrm{CD} 8^{+} \mathrm{T}$ cell responses to HIV peptide stimulation after long-term cryopreservation of PBMC from $\mathrm{HIV}^{+}$individuals and suggest that responses to other peptide antigens may be preserved in both $\mathrm{CD}^{+}$and $\mathrm{CD} 8^{+} \mathrm{T}$ cells. Responses to peptide antigens were also preserved in longterm cryopreserved PBMC from healthy control individuals. A comparable loss of $\mathrm{CD}^{+} \mathrm{T}$ cell responses to HIV peptides was measured in two independent laboratories; therefore the loss was not specific to procedures or personnel from a single laboratory.

One possible explanation for the poor agreement between responses in fresh or short-term cryopreserved samples and long-term cryopreserved samples would be high inter-assay variability, independent of cryopreservation effects. Inter-assay variability was measured at UCSF CIL for stimulation with CMV pp65 and Gag p55 peptide pools. The average coefficient of variation $(\mathrm{CV})$ for six samples stimulated in triplicate with CMV pp65 was $12.43 \%$ (range 2.25 to $30.33 \%$ ) and $5.68 \%$ (range 1.19 to $21.56 \%$ ) for $\mathrm{CD}^{+}$and $\mathrm{CD} 8^{+} \mathrm{T}$ cell IFN- $\gamma$ responses respectively. The average CV for ten samples stimulated in triplicate with Gag p55 peptide pool was $14.01 \%$ (range 1.25 to $27.48 \%$ ) and $4.13 \%$ (range 0.88 to $21.56 \%$ ) for $\mathrm{CD}^{+}$and $\mathrm{CD} 8^{+} \mathrm{T}$ cell IFN- $\gamma$ responses respectively. CV values greater than $20 \%$ were obtained only when the mean IFN- $\gamma$ response was below $0.1 \%$. Infra-assay variability was also determined in frozen PBMC for responses to CMV pp65 peptide pool stimulation. CV values of $17.1 \%$ for $\mathrm{CD}^{+}$and $3.74 \%$ for $\mathrm{CD} 8^{+} \mathrm{T}$ cell IFN- $\gamma$ responses were measured over ten experiments. The degree of inter-assay variability measured using cryopreserved samples was much less than the marked decrement seen in $\mathrm{CD}^{+} \mathrm{T}$ cell responses to HIV Gag p55 peptide pool after long-term cryopreservation, implying that the decrement we measured was due to lack of cell responsiveness and not assay variability.

PBMC isolated and cryopreserved at two independent sites (BSRI and UCSF ASB) from the same phlebotomy for six individuals from the chronic HIV (SCOPE) cohort were tested simultaneously at BSRI in the three-color staining assay following stimulation with SEB, HIV peptides, 555 protein or MN. Similar T cell IFN- $\gamma$ responses with no statistically significant differences were measured in PBMC processed and frozen at BSRI and at UCSF ASB (Fig. $3 \mathrm{a}$ and $\mathrm{b}$ ). Spearman's analysis showed correlation between responses measured in the PBMC processed at the two independent sites. The responses measured in long-term cryopreserved PBMC from BSRI and UCSF ASB showed reduced CD $4^{+}$and $\mathrm{CD} 8^{+}$IFN- $\gamma$ responses when compared to short-term cryopreserved PBMC (data not shown). Therefore, loss of responses was not due to differences in sample processing and cryopreservation methods or shipping of samples between sites.

\subsection{Bland-Altman analysis of $\mathrm{T}$ cell IFN-y responses to peptide and protein antigens}

Since the responses to peptide stimulation appeared to be better preserved than responses to protein antigen, we tested for numeric agreement between fresh whole blood and long-term cryopreserved PBMC responses or between short-term and long-term cryopreserved PBMC responses. The difference between the paired results of each assay was plotted against the mean of the paired results in a Bland-Altman plot (Bland and Altman, 1986). The mean bias between the fresh or short-term cryopreserved and long-term cryopreserved PBMC is shown as a solid line in each plot and the 95\% limits of agreement (dashed lines) are also shown (Fig. 4a and b). A mean bias greater than zero represents loss of responses in the long-term cryopreserved PBMC, and the within-subject variability can be assessed by how close the $95 \%$ limits of agreement are to the bias. For comparison, replicate responses to Gag p55 and CMV pp65 peptide pools were also plotted this way (data not shown). The mean bias of replicate $\mathrm{CD}^{+} \mathrm{T}$ cell responses to $\mathrm{p} 55$ peptide pool stimulation was -0.006 , with $95 \%$ limits of agreement from -0.062 to 0.050 . In contrast, agreement between $\mathrm{CD} 4^{+} \mathrm{T}$ cell IFN- $\gamma$ responses from long-term cryopreserved PBMC and fresh or short-term cryopreserved PBMC was poor, as indicated by 
the mean bias of 0.874 for $\mathrm{CD}^{+} \mathrm{T}$ cell IFN- $\gamma$ responses to individual HIV peptides and of 0.291 for p55 protein stimulation (Fig. 4a). In addition, the $95 \%$ limits of agreements (HIV peptides: -0.958 to 2.706 ; p55 protein: -0.369 to 0.950 ) indicate considerable within-subject variability for the two assay conditions. The mean bias of replicate $\mathrm{CD}^{+} \mathrm{T}$ cell responses to CMV pp65 peptide pool stimulation was -0.013 , with $95 \%$ limits of agreement from -0.067 to 0.041 (data not shown). Comparison of $\mathrm{CD}^{+}{ }^{+} \mathrm{T}$ cell IFN- $\gamma$ responses to $\mathrm{CMV}$ pp65 peptide pool stimulation within fresh whole blood and long-term cryopreserved PBMC showed better agreement in both $\mathrm{HIV}^{+}$and $\mathrm{HIV}^{-}$individuals (mean bias: $\mathrm{HIV}^{+}=-0.307$ and $\mathrm{HIV}^{-}=0.058$ ). Whilst the $95 \%$ limits of agreement for $\mathrm{HIV}^{-}$individuals from -0.014 to 0.130 indicate good within-subject agreement, they were poor (from -3.589 to 2.974) for the $\mathrm{HIV}^{+}$individuals' $\mathrm{CD}^{+} \mathrm{T}$ cell IFN- $\gamma$ responses to CMV pp65 peptide pool stimulation (Fig. 4a).

The mean bias of replicate $\mathrm{CD} 8^{+} \mathrm{T}$ cell IFN- $\gamma$ responses to Gag p55 peptide pool stimulation was 0.015 , with $95 \%$ limits of agreement from -0.096 to 0.126 and to CMV pp65 peptide pool the mean bias was -0.034 , with $95 \%$ limits of agreement from -0.293 to 0.225 (data not shown). The mean bias for $\mathrm{CD} 8^{+} \mathrm{T}$ cell IFN- $\gamma$ responses to individual HIV peptides was 0.281 , with $95 \%$ limits of agreement from -2.344 to 2.906 , indicating considerable within-subject variability for the two types of samples (Fig. 4b). The mean bias for Gag p55 peptide pool stimulation was -0.239 , with $95 \%$ limits of agreement from -0.826 to 0.349 . Comparison of $\mathrm{CD} 8^{+} \mathrm{T}$ cell IFN- $\gamma$ responses to $\mathrm{p} 55$ protein stimulation within fresh or short-term and longterm cryopreserved PBMC showed poor agreement between the two methods, with a large mean bias of 1.858 and wide $95 \%$ limits of agreement (from -1.850 to 5.567) again showing considerable within-subject variability (Fig. 4b). Comparison of $\mathrm{CD}^{+} \mathrm{T}$ cell IFN- $\gamma$ responses to CMV pp65 peptide pool stimulation between fresh whole blood and long-term cryopreserved PBMC showed better agreement in both $\mathrm{HIV}^{+}$and $\mathrm{HIV}^{-}$individuals (mean bias; $\mathrm{HIV}^{+}-0.117$ and $\mathrm{HIV}^{-}=0.039$ ), with the $95 \%$ limits of agreement showing less within-subject variation in the $\mathrm{HIV}^{-}$group (from -0.102 to 0.181 ) than in the $\mathrm{HIV}^{+}$group (from -0.690 to 0.665 ) (Fig. $4 b)$.

Bland-Altman analysis showed considerable variability between the results obtained from the two sample types assayed in $\mathrm{HIV}^{+}$individuals, evidenced by the large spread between the $95 \%$ limits of agreement. In contrast, responses measured in $\mathrm{HIV}^{-}$individuals showed much less variability, as they have closer $95 \%$ limits of agreement for both $\mathrm{CD}^{+}$and $\mathrm{CD} 8^{+} \mathrm{T}$ cell IFN$\gamma$ responses.

\section{4. $\mathrm{CD}^{+} \mathrm{T}$ cell IFN- $\gamma$ responses to peptide stimulation are not restored by exogenous APC}

Loss of T cell IFN- $\gamma$ responses after cryopreservation of PBMC was more pronounced when using whole antigen as a stimulus than with either peptide or superantigen stimuli. One possible explanation for the defect would be a selective decrement in APC function (Makino and Baba, 1997; Waldrop et al., 1998; Lund et al., 2001). To determine whether CD4 ${ }^{+}$or CD8 ${ }^{+}$T cell IFN$\gamma$ responses could be restored, autologous B-LCL from four individuals from the chronic HIV cohort (SCOPE) were pre-pulsed with antigen prior to the addition of PBMC at a 1:1 ratio. Cryopreserved PBMC were from BSRI and UCSF ASB and had been frozen for 546 to 939 days.

The addition of autologous APC did not restore $\mathrm{CD}^{+} \mathrm{T}$ cell IFN- $\gamma$ responses in three individuals tested with HIV peptides (Fig. 5a). Of the four individuals for whom autologous B-LCL plus long-term cryopreserved PBMC were available, only one individual (1092) had a prior $\mathrm{CD} 4^{+} \mathrm{T}$ cell IFN- $\gamma$ response to $\mathrm{p} 55$ protein stimulation. Addition of B-LCL pre-pulsed with $\mathrm{p} 55$ protein to long-term cryopreserved PBMC from this individual partially restored the $\mathrm{CD}^{+} \mathrm{T}$ cell IFN- $\gamma$ response, with a gain of $0.23 \%$ (Table 4 ). In contrast, in the one individual (3169) who had a CD $4^{+} \mathrm{T}$ cell IFN- $\gamma$ response to $\mathrm{MN}$ stimulation in short-term cryopreserved 
PBMC that was lost in the long-term cryopreserved PBMC, addition of autologous B-LCL pre-pulsed with $\mathrm{MN}$ did not restore the response.

Only one of the individuals for whom B-LCL were available exhibited responses to whole HIV protein (p55). The addition of p55 protein pre-pulsed B-LCL almost fully restored the CD8 ${ }^{+}$ T cell IFN- $\gamma$ response in individual 1092 (Fig. 5b) to the level measured in short-term cryopreserved PBMC (a gain of $0.71 \%$, Table 4 ). CD $8^{+}$T cell IFN $-\gamma$ responses to HIV peptides, which were not lost after long-term storage, were not affected by the addition of exogenous APC.

Exogenous co-stimulatory molecules (purified CD28 and CD49d) were added to all chronic PBMC (SCOPE) experiments (data not shown), but a loss of responses was still observed, suggesting the defect is caused by more than a mere lack of co-stimulation.

\subsection{Responses not restored by overnight resting}

Some groups have suggested resting PBMC overnight after thawing before testing effector functions (Lamoreaux et al., 2006; Kierstead et al., 2007). It is possible that the resting process would remove cells destined for death and allow "stunned" cells to recover functional ability. Long-term cryopreserved PBMC from 10 subjects in the chronic HIV cohort (SCOPE) were thawed and split, with half the cells immediately stimulated with individual HIV peptides, p55 protein, MN and SEB. Remaining PBMC were placed in 1-2 $\mathrm{ml}$ of culture media and rested overnight at $37^{\circ} \mathrm{C}, 5 \% \mathrm{CO}_{2}$ to allow a period of recovery. These cells were washed and viability was assessed before stimulating with the same antigens as the cells undergoing immediate stimulation. Cell viability was decreased after resting (cells processed at BSRI had a mean viability of $88 \%$, range $79-96 \%$, and cells from UCSF ASB had a mean viability of $85 \%$, range $68-92 \%$ ), compared to viability immediately post thawing (BSRI cells: mean 94\%, range 88$99 \%, p=0.396$ and UCSF ASB cells: mean 94\%, range 92-97\%, $p=0.007$, Table 2). However, viability was still within an acceptable range and was comparable to the viability of rested PBMC measured at USCF CIL (Table 2) where thawed PBMC are routinely rested overnight prior to stimulation. Overnight resting did not improve the $\mathrm{CD}^{+}$(Fig. 6a) or $\mathrm{CD}^{+}$(Fig. 6b) T cell IFN- $\gamma$ responses to any of the antigens. Table 5 shows the mean change in the percentage T cell IFN- $\gamma$ responses after resting PBMC overnight.

\subsection{Effect of cryopreservation on $\mathrm{T}$ cell phenotype}

While $\mathrm{T}$ cell function showed definite changes after long-term storage, it was not clear if the phenotype of the thawed cells would change. We were particularly interested in the relative effect of cryopreservation on the effector population, as these cells are the focus of most of the functional studies outlined above. The percentages of $\mathrm{CD} 4^{+}$and $\mathrm{CD} 8^{+}$naïve, central memory, and effector memory $\mathrm{T}$ cell populations were enumerated in freshly isolated and long-term cryopreserved PBMC from individuals in the acute HIV cohort (Options). All samples were processed at BSRI and had been cryopreserved for 331 to 537 days. Naïve cells were defined as $\mathrm{CD} 45 \mathrm{RA}^{+} \mathrm{CD} 28^{+} \mathrm{CCR} 7^{+}$, central memory $\mathrm{T}$ cells as $\mathrm{CD} 45 \mathrm{RA}^{-} \mathrm{CD} 28^{+} \mathrm{CCR} 7^{+}$and effector memory $\mathrm{T}$ cells as CD45RA ${ }^{+-} \mathrm{CD}^{2} 8^{-} \mathrm{CCR}^{-}$(Fig. 7a). Samples tested earlier in the study were not stained with CCR7, so analysis of T cell phenotype was performed based on CD45RA and CD28 expression for a subset of individuals.

There was a statistically significant decrease in the percentage of naïve $\mathrm{CD} 4^{+} \mathrm{T}$ cells from the cryopreserved PBMC as compared to fresh PBMC ( $p=0.0003)$. There was no effect of longterm cryopreservation on the $\mathrm{CD} 4^{+}$central memory $\mathrm{T}$ cell population. However, a statistically significant increase in the $\mathrm{CD} 4^{+}$effector memory $\mathrm{T}$ cell population was observed in the cryopreserved PBMC compared to fresh PBMC ( $p=0.030$ ) (Fig. $7 \mathrm{~b}$ ). In contrast to $\mathrm{CD}^{+} \mathrm{T}$ cells, there was a statistically significant decrease in the percentage of naïve $\mathrm{CD} 8^{+} \mathrm{T}$ cells 
( $p=0.044)$ and a statistically significant increase in $\mathrm{CD} 8^{+}$central memory $\mathrm{T}$ cells $(p=0.041)$ measured in long-term cryopreserved PBMC compared to freshly isolated PBMC. There was no statistically significant alteration in the percentage of effector memory $\mathrm{CD} 8^{+} \mathrm{T}$ cells following long-term cryopreservation (Fig. 7c), however, Bland-Altman analysis shows large $95 \%$ limits of agreement (from -31.53 to 34.30 ), suggesting a high degree of variability seen within individuals.

These data suggest that selective loss of effector cell populations does not account for the loss of $\mathrm{CD}^{+}$or $\mathrm{CD}^{+} \mathrm{T}$ cell IFN- $\gamma$ responses to antigenic stimulation in cryopreserved PBMC.

\subsection{Cryopreservation increases $\mathrm{CD}^{+} \mathrm{T}$ cell apoptosis after antigenic stimulation}

While effector cells appear to be present after long-term cryopreservation, it is possible that an increased propensity to apoptosis blunts their ability to respond to antigenic stimulation. The level of apoptosis was measured at BSRI by staining for activated caspase- 3 in $\mathrm{CD} 4^{+}$IFN$\gamma^{-}$(Fig. 8a) and CD8 ${ }^{+}$IFN- $\gamma^{-}$(Fig. 8b) T cells from freshly isolated and long-term cryopreserved PBMC (331 to 537 days) from individuals in the acute HIV infection cohort. Long-term cryopreserved CD $4^{+}$IFN- $\gamma^{-}$T cells in samples stimulated with SEB and 555 protein had statistically significant increases in the percentage of caspase $-3^{+}$cells $(p=0.016$ and 0.049 respectively) and a non-significant trend towards increased levels of caspase- $3^{+} \mathrm{CD} 4^{+}$cells when they were stimulated with CMV lysate. These data imply that a population of $\mathrm{CD} 4^{+} \mathrm{T}$ cells specific for the stimulating antigen is undergoing apoptosis and is unable to secrete IFN$\gamma$ in the long-term cryopreserved samples.

\section{Discussion}

Our findings show that long-term eryopreservation of PBMC from HIV infected individuals resulted in a loss of IFN- $\gamma$ responses to antigenic stimulation with whole proteins or individual $\mathrm{HIV}$ peptides and peptide pools in $\mathrm{CD} 4^{+} \mathrm{T}$ cells and whole protein antigens in $\mathrm{CD} 8^{+} \mathrm{T}$ cells. In contrast to HIV peptide responses, $\mathrm{CD}^{+}{ }^{+} \mathrm{T}$ cell IFN- $\gamma$ responses to $\mathrm{CMV}$ pp65 peptide pools were maintained in both $\mathrm{HIV}^{-}$and $\mathrm{HIV}^{+}$individuals. Adding exogenous APC did not restore $\mathrm{CD}^{+} \mathrm{T}$ cell IFN- $\gamma$ responses to individual HIV peptide stimulation. However, in the one individual tested, autologous B-LCL partially restored T cell IFN- $\gamma$ responses to p55 protein stimulation. Cryopreservation increased $\mathrm{CD}^{+} \mathrm{T}$ cell apoptosis after antigenic stimulation, possibly contributing to the loss of responses. Our findings also suggest that the effect of cryopreservation becomes more significant over time, with the most significant reductions in responses observed in samples that were stored for longer than 300 days.

PBMC responses following long-term cryopreservation were compared with either short-term cryopreserved or fresh responses by testing for differences (using a paired, two-tailed $t$ test) and association (Spearman's correlation). Significant reductions were found in $\mathrm{CD} 4^{+} \mathrm{T}$ cell IFN- $\gamma$ responses to 555 protein, p55 peptide pools and CMV lysate in $\mathrm{HIV}^{+}$individuals and to $\mathrm{CMV}$ pp65 peptide pools in $\mathrm{HIV}^{-}$individuals after long-term cryopreservation. However, a significant difference did not always indicate that long-term cryopreserved PBMC samples cannot be used for evaluation of CD4 ${ }^{+} \mathrm{T}$ cell IFN- $\gamma$ responses. Despite the observed difference in $\mathrm{CD}^{+} \mathrm{T}$ cell responses to the CMV pp65 peptide pool stimulation in $\mathrm{HIV}^{-}$individuals, the excellent correlation between fresh and long-term cryopreserved responses indicated that the rank order of the responses was maintained, and that reduced responses were consistent enough that data obtained from fresh and long-term cryopreserved PBMC would give similar results on a population basis. Conversely, whilst there was no significant difference in the $\mathrm{CD} 4^{+} \mathrm{T}$ cell IFN- $\gamma$ responses to stimulation with individual HIV peptides, MN or SEB between the long-term and short-term cryopreserved PBMC, there was a lack of correlation between responses from cells cryopreserved for different lengths of time. This indicated that responses 
from long-term cryopreserved samples have been lost to a variable degree and are not comparable to the responses from short-term cryopreserved PBMC.

$\mathrm{CD} 8{ }^{+} \mathrm{T}$ cell IFN- $\gamma$ responses to all of the peptides tested correlated strongly between shortterm and long-term cryopreserved PBMC. Whilst a strong correlation indicates that data from one set of samples may give comparable results to data from another group, it does not indicate that data from the two types of samples are equivalent. For example, if a study included samples that have been cryopreserved for short- and long-term, it would be important to know the results would not be biased by the length of time the samples had been stored. To test for agreement in T cell IFN- $\gamma$ responses between fresh or short-term cryopreserved and long-term cryopreserved samples we used Bland-Altman analysis. An increase in the mean bias above zero represents a loss of responses in long-term cryopreserved PBMC and the within-subject variability can also be assessed by the $95 \%$ limits of agreement. Bland-Altman analysis showed there was a bias towards higher results from fresh or short-term cryopreserved samples when compared with long-term cryopreserved samples, and considerable variability in $\mathrm{HIV}^{+}$ individuals' $\mathrm{CD} 8^{+} \mathrm{T}$ cell IFN- $\gamma$ responses to CMV pp65 and Gag p55 peptide stimulation, despite strong correlations between responses found using fresh or short-term cryopreserved samples and long-term cryopreserved samples. In contrast, CMV pp65 stimulated samples from $\mathrm{HIV}^{-}$subjects showed very little bias and good limits of agreement. These data suggest that cryopreservation introduces more variability in samples from $\mathrm{HIV}^{+}$individuals, whilst samples from $\mathrm{HIV}^{-}$individuals may be less sensitive to the effects of long-term cryopreservation. It would be important in novel studies of cryopreserved PBMC from HIV infected individuals to establish the effect of cryopreservation on the responses being measured.

The loss of responses cannot be attributed to cryopreservation technique or to the shipping of samples, as suggested in previous studies (Disis et al., 2006;Bull et al., 2007;Kierstead et al., 2007), as similar losses were measured in samples processed and frozen at three independent laboratories. These changes occurred despite the observation that cell viability was generally maintained at acceptable levels of 81-95\% (Table 2). Additionally, processing and storing of PBMC performed at UCSF ASB was with state-of-the-art cryopreservation techniques, and has routinely met all internal and external quality control monitoring.

Differences in the processing and presentation of whole protein and peptide antigens may explain the greater loss of $\mathrm{T}$ cell responses to whole protein antigens versus individual peptides. APC such as monocytes and macrophages preferentially process whole proteins via the exogenous pathway of antigen presentation (Braciale et al., 1987;Monaco, 1995). In contrast, short peptides spanning immunodominant epitopes can bind directly into the MHC groove, bypassing the requirement for protein internalization and processing (Kern et al., 1998; He et al., 2001). Previous research has shown that $\mathrm{CD} 4^{+} \mathrm{T}$ cell responses induced by peptide mixes are equal to those induced by whole proteins (Maecker et al., 2001) whilst CD8 ${ }^{+} \mathrm{T}$ cell responses can be significantly higher after peptide compared to whole protein stimulation, presumably a result of bypassing the antigen internalization and processing requirement. Previous reports found that cryopreservation has detrimental effects on APC such as monocytes and dendritic cells (Makino and Baba, 1997;Waldrop et al., 1998;Lund et al., 2001). Therefore, impaired APC internalization and processing of whole protein antigens (such as HIV p55 protein and CMV lysate) may lead to the loss or impairment of presentation of whole protein antigens to T cells. In contrast, peptide stimuli are not dependent on fully functional APC function and this may contribute to the maintenance of $\mathrm{CD} 8^{+} \mathrm{T}$ cell IFN- $\gamma$ responses to HIV peptides in long-term cryopreserved PBMC.

While impaired APC function may explain loss of $\mathrm{T}$ cell responses to whole proteins, the marked decrease in $\mathrm{CD}^{+} \mathrm{T}$ cell responses to HIV peptides does not appear to be APC- 
dependent. Interestingly, $\mathrm{CD}^{+}{ }^{+} \mathrm{T}$ cells from $\mathrm{HIV}^{+}$individuals with reduced response to the HIV p55 peptide pool retained their ability to respond to CMV peptides, suggesting a defect in the HIV-specific $\mathrm{CD}^{+} \mathrm{T}$ cells rather than in the APC. Supporting the concept of a primary $\mathrm{CD}^{+} \mathrm{T}$ cell defect, the addition of exogenous APC pre-pulsed with individual HIV peptides could not restore lost $\mathrm{CD} 4^{+} \mathrm{T}$ cell IFN- $\gamma$ responses. However, a defect in the processing and presentation of whole protein antigens may play a role in the loss of responses to $\mathrm{p} 55$ protein, as exogenous, autologous B-LCL pre-pulsed with p55 protein could partially restore T cell IFN- $\gamma$ responses in the one individual tested. A study by Kreher et al. (2003) reports that addition of exogenous APC to previously frozen murine splenic cells could not improve responses in T cell ELISPOT assays. Defining the mechanism by which exogenous APC restore $\mathrm{T}$ cell responses to whole protein antigens in cryopreserved PBMC remains an interesting area of research.

Defective co-stimulation would also prevent the efficient induction of $\mathrm{T}$ cell responses to antigenic stimulation. We added exogenous CD28 and CD49d to assays using PBMC from the chronic HIV cohort and in all assays performed at UCSF CIL, suggesting the defect in longterm cryopreserved cells represents more than a simple lack of co-stimulation. However, cryopreservation may have had detrimental effects upon other co-stimulatory molecules such as CD40-CD40L and 4-1BBL (DeBenedette et al., 1997), thus impairing the induction of T cell responses. Conversely, cryopreservation may induce upregulation of negative regulators of T cell activation, such as CTLA-4 and PD-1 (Chambers and Allison, 1997;Okazaki et al., 2002;Blattman and Greenberg, 2006), which may result in the lack of T cell responses. Our studies did not examine the expression of co-stimulatory molecules and ligands on either $\mathrm{T}$ cells or APC, though this warrants further investigation in cryopreserved PBMC.

It has been suggested that using PBMC directly after thawing has detrimental effects on the measurement of T cell responses. Lamoreaux et al. (2006) found that resting PBMC can reduce background cytokine responses and therefore increase the specificity of the T cell response. Kierstead et al. (2007) also report that resting cells overnight post thawing is essential for measurement of optimal $\mathrm{T}$ cell responses by ELISPOT or intracellular cytokine staining. This is thought to be due to cells requiring a period of recovery following the harsh procedure of thawing to allow any cells which may be apoptotic or necrotic to die, leaving a healthy population of cells for functional studies. Indeed, as Kierstead et al. (2007) report, we also measured a reduction in cell viability after resting, compared to immediately post thawing, suggesting that a population of cells still undergoes apoptosis or necrosis following thawing, even after an $18 \mathrm{~h}$ period of rest. However, our BSRI laboratory routinely uses PBMC directly after thawing without resting and has measured good $\mathrm{T}$ cell responses in short-term cryopreserved PBMC (Fig. 1). Additionally, losses in $\mathrm{CD}^{+} \mathrm{T}$ cell IFN- $\gamma$ responses were measured at UCSF CIL, where thawed PBMC are routinely rested overnight (Fig. 2). We also compared unrested PBMC with rested PBMC from the same individuals following long-term cryopreservation and found no recovery of T cell IFN- $\gamma$ responses (Fig. 6). We conclude that it was not necessary to rest PBMC before stimulation with antigen and that resting could not overcome the loss of $\mathrm{T}$ cell responses following long-term cryopreservation. These findings are consistent with those of Maecker et al. (2001).

Cryopreservation is known to alter the expression of surface markers used to define $\mathrm{T}$ cell phenotype, such as CD62L (Tollerud et al., 1991;Romeu et al., 1992;Rosillo et al., 1995;Koenigsmann et al., 1998;Hattori et al., 2001;Cavers et al., 2002;Costantini et al., 2003). Our study avoided such markers and used others (CD28 and CCR7) that are not lost on previously frozen PBMC (Hamann et al., 1997; Hislop et al., 2001;Palmer et al., 2004; Yue et al., 2004). Costantini et al. (2003) reported an increase in CD45RA expression on cryopreserved PBMC. This may account for the increase in effector memory T cells measured, defined as CD45RA ${ }^{+/-}$CD28 $8^{-}$. In contrast, Reimann et al. (2000) found a decrease in CD45RA 
and CD62L expression following cryopreservation and a loss of naïve T cells. Our results also showed a loss of naive $\mathrm{CD}^{+}$and $\mathrm{CD}^{+} \mathrm{T}$ cells, due to a decrease in staining of $\mathrm{CD} 28$ on $\mathrm{CD}^{+} \mathrm{T}$ cells and of CD45RA on $\mathrm{CD}^{+} \mathrm{T}$ cells. Costantini et al. (2003) also report a loss of naiive $\mathrm{CD}^{+}{ }^{+}$and $\mathrm{CD}^{+} \mathrm{T}$ cells after cryopreservation. The alteration in expression of surface markers used to define populations will be important to consider in future studies, as T cell populations may be under- or overestimated in cryopreserved PBMC. However, this may not be a problem in longitudinal studies where only cryopreserved cells are used. Clearly caution must be taken that phenotypic analyses from fresh and frozen PBMC should not be mixed in the same analysis.

Our data suggest that cryopreservation induces higher levels of apoptosis in antigen-specific $\mathrm{CD}^{+} \mathrm{T}$ cells than in freshly isolated cells. Caspase activation plays a central role in the induction of apoptosis, and once caspase- 3 is activated the cell will undergo apoptosis (Longthorne and Williams, 1997;Budihardjo et al., 1999;Los et al., 2001). Previous studies found cryopreservation induces higher levels of apoptosis in PBMC (Fowke et al., 2000; Stroh et al., 2002). Therefore, it was not surprising that we observed a similar effect. The higher percentage of $\mathrm{CD}^{+}$IFN- $\gamma^{-}$caspase- $3^{+} \mathrm{T}$ cells in cryopreserved PBMC that had been stimulated with SEB or 555 protein suggests that apoptosis induced by cryopreservation may be eliminating $\mathrm{CD}^{+} \mathrm{T}$ cells that could potentially respond to HIV or other stimuli. This may help explain the marked decrement in antigen-specific $\mathrm{CD}^{+} \mathrm{T}$ cell responses seen following long-term cryopreservation. T cells from HIV infected individuals appear to be more fragile and more susceptible to the effects of freezing and thawing than those from healthy, uninfected individuals, as we saw greater losses of responses in HIV infected individuals than in uninfected individuals.

Sarkar et al. (2003) found high levels of apoptosis of CD4 ${ }^{+}$T cells from SIV infected and uninfected macaques following cryopreservation of PBMC. They report the use of caspase inhibitors and cytokine cocktails to block cryopreservation-induced apoptosis by inducing upregulation of anti-apoptotic proteins such as Bcl-2 and Bcl-xL. The use of cytokines such as IL-2, IL-4, IL-7 and IL-15, which are know to act as survival factors from in vitro and in vivo studies (Amos et al., 1998;Baust et al., 2000;Keller and Borst, 2006), also may have the potential to rescue responses in human cryopreserved PBMC (Jennes et al., 2002). The use of caspase inhibitors to rescue cells following cryopreservation needs to be evaluated, as they may have detrimental effects on cell function (Alam et al., 1999). If more cells, particularly the $\mathrm{CD}^{+} \mathrm{T}$ cells, can be rescued without phenotypic or functional alterations postcryopreservation, this would remove barriers to the future use of cryopreserved PBMC.

Cryopreservation of cells offers many advantages to the research community, such as the banking of multiple aliquots of cells from multi-center studies of large cohorts of individuals, allowing precious samples to be available for future studies, often using newly developed techniques or assays. Additionally, sequential samples banked over time can be simultaneously processed allowing greater control of assay conditions and reducing per assay costs. Reimann et al. (2000) found the extent of the decrease in responses varied among individuals, consistent with our current findings. Therefore, infra-donor variation must be considered when using cryopreserved PBMC. Most previous studies have not explored the effect of long-term cryopreservation on the functional responses of PBMC. We found that PBMC from HIV infected cohorts frozen for approximately one year or longer did not maintain their ability to respond to some antigens. Both $\mathrm{CD}^{+}$and $\mathrm{CD}^{+} \mathrm{T}$ cells lost their ability to respond to whole protein antigens. $\mathrm{CD}^{+} \mathrm{T}$ cell responses to individual peptides and peptide pools were preserved, whilst $\mathrm{CD}^{+}{ }^{+} \mathrm{T}$ cells lost the ability to respond to HIV but not CMV peptides. PBMC cryopreserved for less than six months responded to HIV peptides and proteins with a higher magnitude of responses than we observed in long-term cryopreserved PBMC, suggesting 
responses may be preserved over the short-term. However, responses from fresh and shortterm cryopreserved PBMC were not directly compared in the current study.

Our study could have major implications on the current practice of longitudinal storage of PBMC samples for future studies that rely upon the long-term storage of specimens prior to evaluation of T cell responses, particularly within the field of HIV immunology and vaccine research. Samples from $\mathrm{HIV}^{+}$cohorts that have been stored for approximately one year or longer may not be suitable for measurement of $\mathrm{CD}^{+} \mathrm{T}$ cell cytokine responses. It will be essential to evaluate the effect of cryopreservation upon responses to individual antigens being measured in each study. The timing of future studies using cryopreserved samples must be carefully considered both in study design and for the establishment of specimen banks. However, even if a loss of responses is measured (as shown by two-tailed, paired $t$ tests), data from long-term cryopreserved PBMC could remain useful if the relative ranks of loss are preserved. Long-term cryopreservation of PBMC is likely acceptable for vaccination studies of $\mathrm{HIV}^{-}$individuals where peptides are used to stimulate $\mathrm{T}$ cells, particularly for analysis of $\mathrm{CD} 8^{+} \mathrm{T}$ cell responses. Samples from $\mathrm{HIV}^{+}$individuals that have been cryopreserved for long periods of time may remain useful for testing $\mathrm{T}$ cell responses to mitogens or $\mathrm{CD} 8^{+} \mathrm{T}$ cell responses to peptide antigens.

\section{Acknowledgements}

This work was supported in part by grants from the NIH (AI052745, AI055273 to SGD, AI41531 to FMH and AI49538 to MAJ), the NIH UCSF/Gladstone Institute of Virology \& Immunology Center for AIDS Research (P30 AI27763 to REO, P30 MH59037), and the Center for AIDS Prevention Studies (P30 MH62246). The work done in the Core Immunology Laboratory was supported by grants from the NCRR to the General Clinical Research Center at San Francisco General Hospital (NCRR M01 RR00083); from the NIH to the UCSF Clinical and Translational Sciences Institute (U54RR023566); from the NIH to the UCSF/GIVI Center for AIDS Research (5P30AI027763) and from the NIH to JMM (AI47062). JMM is a recipient of the Burroughs Wellcome Fund Clinical Scientist Award in Translational Research and the NIH Director's Pioneer Award Program, part of the NIH Roadmap for Medical Research, through grant number DPI OD00329.

The UCSF AIDS Specimen Bank provided cryopreserved PBMC from the SCOPE cohort. MN was a kind gift of Jeffrey D. Lifson (AIDS Vaccine Program, NCI, Frederick, MD). Gag and CMV peptide pools were a kind gift of Holden T. Maecker (BD Biosciences, San Jose, CA).

\section{References}

Alam A, Cohen LY, Aouad S, Sekaly RP. Early activation of caspases during T lymphocyte stimulation results in selective substrate cleavage in nonapoptotic cells. J. Exp. Med 1999;190:1879. [PubMed: 10601362]

Altfeld M, Rosenberg ES, Shankarappa R, Mukherjee JS, Hecht FM, Eldridge RL, Addo MM, Poon SH, Phillips MN, Robbins GK, Sax PE, Boswell S, Kahn JO, Brander C, Goulder PJ, Levy JA, Mullins JI, Walker BD. Cellular immune responses and viral diversity in individuals treated during acute and early HIV-1 infection. J. Exp. Med 2001;193:169. [PubMed: 11148221]

Amos CL, Woetmann A, Nielsen M, Geisler C, Odum N, Brown BL, Dobson PR. The role of caspase 3 and BclxL in the action of interleukin 7 (IL-7): a survival factor in activated human T cells. Cytokin 1998;10:662.

Baust JM, Van B, Baust JG. Cell viability improves following inhibition of cryopreservation-induced apoptosis. In Vitro Cell. Dev Biol., Anim 2000;36:262. [PubMed: 10852352]

Birkeland SA. Cryopreservation of human lymphocytes for sequential testing of immune competence. J. Immunol. Methods 1980;35:57. [PubMed: 7204989]

Bland JM, Altman DG. Statistical methods for assessing agreement between two methods of clinical measurement. Lancet 1986;1:307. [PubMed: 2868172]

Blattman JN, Greenberg PD. PD-1 blockade: rescue from a near-death experience. Nat. Immunol 2006;7:227. [PubMed: 16482167] 
Borrow P, Lewicki H, Hahn BH, Shaw GM, Oldstone MB. Virus-specific CD8 ${ }^{+}$cytotoxic T-lymphocyte activity associated with control of viremia in primary human immunodeficiency virus type 1 infection. J. Virol 1994;68:6103. [PubMed: 8057491]

Braciale TJ, Morrison LA, Sweetser MT, Sambrook J, Gething MJ, Braciale VL. Antigen presentation pathways to class I and class II MHC-restricted T lymphocytes. Immunol. Rev 1987;98:95. [PubMed: 2443444]

Budihardjo I, Oliver H, Lutter M, Luo X, Wang X. Biochemical pathways of caspase activation during apoptosis. Annu. Rev. Cell Dev. Biol 1999;15:269. [PubMed: 10611963]

Bull M, Lee D, Stucky J, Chiu YL, Rubin A, Horton H, McElrath MJ. Defining blood processing parameters for optimal detection of cryopreserved antigen-specific responses for HIV vaccine trials. J. Immunol. Methods 2007;322:57. [PubMed: 17382342]

Cavers M, Afzali B, Macey M, McCarthy DA, Irshad S, Brown KA. Differential expression of beta1 and beta2 integrins and l-selectin on $\mathrm{CD}^{+}$and $\mathrm{CD} 8^{+} \mathrm{T}$ lymphocytes in human blood: comparative analysis between isolated cells, whole blood samples and cryopreserved preparations. Clin. Exp. Immunol 2002;127:60. [PubMed: 11882033]

Chambers CA, Allison JP. Co-stimulation in T cell responses. Curr. Opin. Immunol 1997;9:396. [PubMed: 9203422]

Coligan, JE. Isolation of whole mononuclear cells from peripheral blood and cord blood. In: Coligan, JE., editor. Current Protocols in Immunology. John Wiley and Sons, Inc.: New York; 2007.

Costantini A, Mancini S, Giuliodoro S, Butini L, Regnery CM, Silvestri G, Montroni M. Effects of cryopreservation on lymphocyte immunophenotype and function. J. Immunol. Methods 2003;278:145. [PubMed: 12957403]

DeBenedette MA, Shahinian A, Mak TW, Watts TH. Costimulation of CD28-T lymphocytes by 4-1BB ligand. J. Immunol 1997;158:551. [PubMed: 8992967]

Disis ML, dela Rosa C, Goodell V, Kuan LY, Chang JC, Kuus-Reichel K, Clay TM, Kim Lyerly H, Bhatia S, Ghanekar SA, Maino VC, Maecker HT. Maximizing the retention of antigen specific lymphocyte function after cryopreservation. J. Immunol. Methods 2006;308:13. [PubMed: 16337957]

Emu B, Sinclair E, Favre D, Moretto WJ, Hsue P, Hoh R, Martin JN, Nixon DF, McCune JM, Deeks SG. Phenotypic, functional, and kinetic parameters associated with apparent T-cell control of human immunodeficiency virus replication in individuals with and without antiretroviral treatment. J. Virol 2005;79:14169. [PubMed: 16254352]

Fowke KR, Behnke J, Hanson C, Shea K, Cosentino LM. Apoptosis: a method for evaluating the cryopreservation of whole blood and peripheral blood mononuclear cells. J. Immunol. Methods 2000;244:139. [PubMed: 11033026]

Gao D, Critser JK. Mechanisms of cryoinjury in living cells. ILAR J 2000;41:187. [PubMed: 11123179]

Hamann D, Baars PA, Rep MH, Hooibrink B, Kerkhof-Garde SR, Klein MR, van Lier RA. Phenotypic and functional separation of memory and effector human CD8 ${ }^{+}$T cells. J. Exp. Med 1997;186:1407. [PubMed: 9348298]

Hattori Y, Kato H, Nitta M, Takamoto S. Decrease of 1-selectin expression on human CD34 ${ }^{+}$cells on freeze-thawing and rapid recovery with short-term incubation. Exp. Hematol 2001;29:114. [PubMed: 11164112]

Hayes RB, Smith CO, Huang WY, Read Y, Kopp WC. Whole blood cryopreservation in epidemiological studies. Cancer Epidemiol. Biomark. Prev 2002;11:1496.

He XS, Rehermann B, Boisvert J, Mumm J, Maecker HT, Roederer M, Wright TL, Maino VC, Davis $\mathrm{MM}$, Greenberg HB. Direct functional analysis of epitope-specific $\mathrm{CD} 8^{+} \mathrm{T}$ cells in peripheral blood. Viral. Immunol 2001;14:59. [PubMed: 11270597]

Hislop AD, Gudgeon NH, Callan MF, Fazou C, Hasegawa H, Salmon M, Rickinson AB. EBV-specific $\mathrm{CD}^{+} \mathrm{T}$ cell memory: relationships between epitope specificity, cell phenotype, and immediate effector function. J. Immunol 2001;167:2019. [PubMed: 11489984]

Janssen RS, Satten GA, Stramer SL, Rawal BD, O'Brien TR, Weiblen BJ, Hecht FM, Jack N, Cleghorn FR, Kahn JO, Chesney MA, Busch MP. New testing strategy to detect early HIV-1 infection for use in incidence estimates and for clinical and prevention purposes. JAMA 1998;280:42. [PubMed: 9660362] 
Jennes W, Kestens L, Nixon DF, Shacklett BL. Enhanced ELISPOT detection of antigen-specific T cell responses from cryopreserved specimens with addition of both IL-7 and IL-15-the Amplispot assay. J. Immunol. Methods 2002;270:99. [PubMed: 12379342]

Keller AM, Borst J. Control of peripheral T cell survival: a delicate division of labor between cytokines and costimulatory molecules. Hum. Immunol 2006;67:469. [PubMed: 16728271]

Kern F, Surel IP, Brock C, Freistedt B, Radtke H, Scheffold A, Blasczyk R, Reinke P, SchneiderMergener J, Radbruch A, Walden P, Volk HD. T-cell epitope mapping by flow cytometry. Nat. Med 1998;4:975. [PubMed: 9701254]

Kierstead LS, Dubey S, Meyer B, Tobery TW, Mogg R, Fernandez VR, Long R, Guan L, Gaunt C, Collins K, Sykes KJ, Mehrotra DV, Chirmule N, Shiver JW, Casimiro DR. Enhanced rates and magnitude of immune responses detected against an hiv vaccine: effect of using an optimized process for isolating PBMC. AIDS Res. Hum. Retrovir 2007;23:86. [PubMed: 17263637]

Koenigsmann MP, Koenigsmann M, Notter M, Neuloh M, Mucke C, Thiel E, Berdel WE. Adhesion molecules on peripheral blood-derived $\mathrm{CD} 34^{+}$cells: effects of cryopreservation and short-term ex vivo incubation with serum and cytokines. Bone Marrow Transplant 1998;22:1077. [PubMed: 9877270]

Kreher CR, Dittrich MT, Guerkov R, Boehm BO, Tary-Lehmann M. CD4 ${ }^{+}$and CD8 ${ }^{+}$cells in cryopreserved human PBMC maintain full functionality in cytokine ELISPOT assays. J. Immunol. Methods 2003;278:79. [PubMed: 12957398]

Lamoreaux L, Roederer M, Koup R. Intracellular cytokine optimization and standard operating procedure. Nat. Protoc 2006;1:1507. [PubMed: 17406442]

Longthorne VL, Williams GT. Caspase activity is required for commitment to Fas-mediated apoptosis. EMBO J 1997;16:3805. [PubMed: 9233790]

Los M, Stroh C, Janicke RU, Engels IH, Schulze-Osthoff K. Caspases: more than just killers? Trends Immunol 2001;22:31. [PubMed: 11286689]

Lund PK, Westvik AB, Joo GB, Ovstebo R, Haug KB, Kierulf P. Flow cytometric evaluation of apoptosis, necrosis and recovery when culturing monocytes. J. Immunol. Methods 2001;252:45. [PubMed: 11334964]

Maecker HT, Dunn HS, Suni MA, Khatamzas E, Pitcher CJ, Bunde T, Persaud N, Trigona W, Fu TM, Sinclair E, Bredt BM, McCune JM, Maino VC, Kern F, Picker LJ. Use of overlapping peptide mixtures as antigens for cytokine flow cytometry. J. Immunol. Methods 2001;255:27. [PubMed: 11470284]

Maecker HT, Moon J, Bhatia S, Ghanekar SA, Maino VC, Payne JK, Kuus-Reichel K, Chang JC, Summers A, Clay TM, Morse MA, Lyerly HK, DeLaRosa C, Ankerst DP, Disis ML. Impact of cryopreservation on tetramer, cytokine flow cytometry, and ELISPOT. BMC Immunol 2005;6:17. [PubMed: 16026627]

Makino M, Baba M. A cryopreservation method of human peripheral blood mononuclear cells for efficient production of dendritic cells. Scand. J. Immunol 1997;45:618. [PubMed: 9201301]

McMichael AJ, Rowland-Jones SL. Cellular immune responses to HIV. Nature 2001;410:980. [PubMed: 11309628]

Miniscalco B, D’Angelo A, Cagnasso A. Effect of storage and cryopreservation on the lymphocyte responses to polyclonal mitogens in cattle. Vet. Res. Commun 2003;27:775. [PubMed: 14535519]

Monaco JJ. Pathways for the processing and presentation of antigens to T cells. J. Leukoc. Biol 1995;57:543. [PubMed: 7722412]

Okazaki T, Iwai Y, Honjo T. New regulatory co-receptors: inducible co-stimulator and PD-1. Curr. Opin. Immunol 2002;14:779. [PubMed: 12413529]

Palmer BE, Boritz E, Wilson CC. Effects of sustained HIV-1 plasma viremia on HIV-1 Gag-specific $\mathrm{CD}^{+} \mathrm{T}$ cell maturation and function. J. Immunol 2004;172:3337. [PubMed: 14978142]

Reimann KA, Chernoff M, Wilkening CL, Nickerson CE, Landay AL. Preservation of lymphocyte immunopheno-type and proliferative responses in cryopreserved peripheral blood mononuclear cells from human immunodeficiency virus type 1-infected donors: implications for multicenter clinical trials. The ACTG immunology advanced technology laboratories. Clin. Diagn. Lab. Immunol 2000;7:352. [PubMed: 10799445] 
Romeu MA, Mestre M, Gonzalez L, Valls A, Verdaguer J, Corominas M, Bas J, Massip E, Buendia E. Lymphocyte immunophenotyping by flow cytometry in normal adults. Comparison of fresh whole blood lysis technique, Ficoll-Paque separation and cryopreservation. J. Immunol. Methods 1992;154:7. [PubMed: 1401946]

Rosenberg ES, Billingsley JM, Caliendo AM, Boswell SL, Sax PE, Kalams SA, Walker BD. Vigorous HIV-1-specific CD4 ${ }^{+}$T cell responses associated with control of viremia. Science 1997;278:1447. [PubMed: 9367954]

Rosillo MC, Ortuno F, Rivera J, Moraleda JM, Vicente V. Cryopreservation modifies flow-cytometric analysis of hemopoietic cells. Vox Sang 1995;68:210. [PubMed: 7660638]

Sarkar S, Kalia V, Montelaro RC. Caspase-mediated apoptosis and cell death of rhesus macaque CD4 ${ }^{+}$ T-cells due to cryopreservation of peripheral blood mononuclear cells can be rescued by cytokine treatment after thawing. Cryobiology 2003;47:44. [PubMed: 12963412]

Smith JG, Joseph HR, Green T, Field JA, Wooters M, Kaufhold RM, Antonello J, Caulfield MJ. Establishing acceptance criteria for cell-mediated immunity assays using frozen peripheral blood mononuclear cells stored under optimal and suboptimal conditions. Clin. Vaccine Immunol 2007;14:527. [PubMed: 17376862]

Sobota V, Bubenik J, Indrova M, Vlk V, Jakoubkova J. Use of cryopreserved lymphocytes for assessment of the immunological effects of interferon therapy in renal cell carcinoma patients. J. Immunol. Methods 1997;203:1. [PubMed: 9134025]

Stroh C, Cassens U, Samraj AK, Sibrowski W, Schulze-Osthoff K, Los M. The role of caspases in cryoinjury: caspase inhibition strongly improves the recovery of cryopreserved hematopoietic and other cells. FASEB J 2002;16:1651. [PubMed: 12207004]

Tollerud DJ, Brown LM, Clark JW, Neuland CY, Mann DL, Pankiw-Trost LK, Blattner WA. Cryopreservation and long-term liquid nitrogen storage of peripheral blood mononuclear cells for flow cytometry analysis: effects on cell subset proportions and fluorescence intensity. J. Clin. Lab. Anal 1991;5:255. [PubMed: 1890539]

Waldrop SL, Davis KA, Maino VC, Picker LJ. Normal human CD4 ${ }^{+}$memory T cells display broad heterogeneity in their activation threshold for cytokine synthesis. J. Immunol 1998;161:5284. [PubMed: 9820501]

Weinberg A, Betensky RA, Zhang L, Ray G. Effect of shipment, storage, anticoagulant, and cell separation on lymphocyte proliferation assays for human immunodeficiency virus infected patients. Clin. Diagn. Lab. Immunol 1998;5:804. [PubMed: 9801338]

Weinberg A, Zhang L, Brown D, Erice A, Polsky B, Hirsch MS, Owens S, Lamb K. Viability and functional activity of cryopreserved mononuclear cells. Clin. Diagn. Lab. Immunol 2000;7:714. [PubMed: 10882680]

Yue FY, Kovacs CM, Dimayuga RC, Parks P, Ostrowski MA. HIV-1-specific memory CD4 ${ }^{+}$T cells are phenotypically less mature than cytomegalovirus-specific memory CD4 ${ }^{+} \mathrm{T}$ cells. J. Immunol 2004;172:2476. [PubMed: 14764720]

\section{Abbreviations}

PBMC, peripheral blood mononuclear cells; HIV, human immunodeficiency virus; FBS, fetal bovine serum; CMV, cytomegalovirus; DMSO, dimethyl sulphoxide; STI, structured treatment interruption; LTNP, long-term non-progressor; B-LCL, B lymphoblastoid cell line; SEB, Staphylococcal enterotoxin B; FMO, fluorescence minus one; EMA, ethidium monoazide; EBV, Epstein Barr virus; APC, antigen presenting cell; MHC, major histocompatibility complex; SIV, simian immunodeficiency virus. 
a
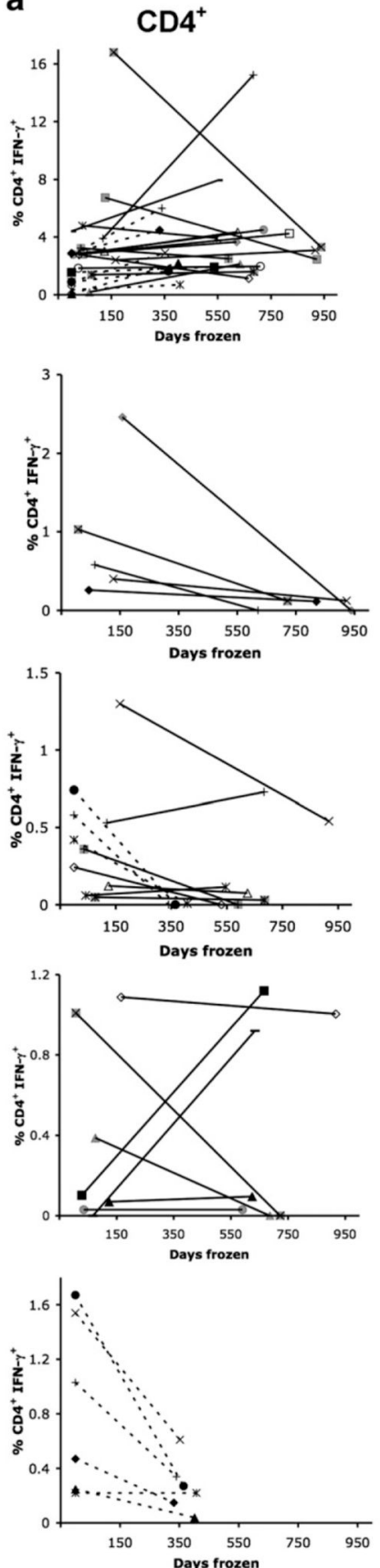

b $\quad \mathrm{CD}^{+}$
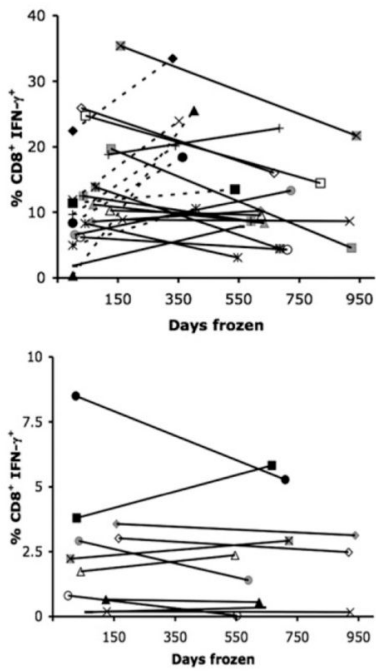

peptides

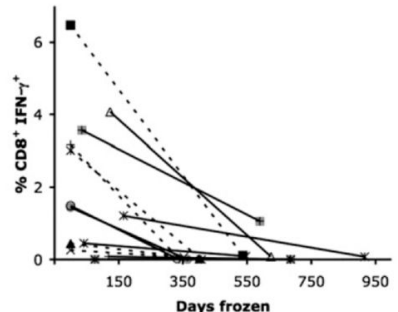

protein
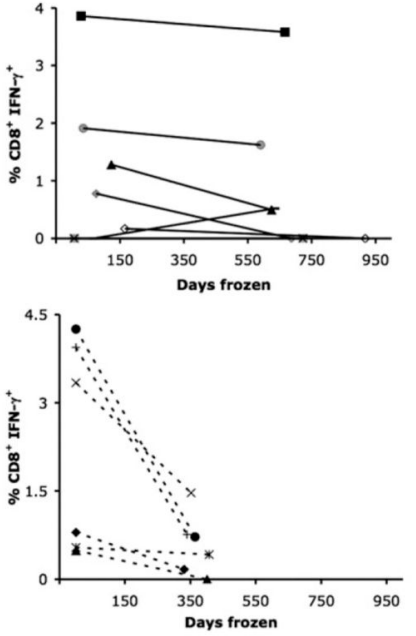

HIV

p55

MN

CMV

SEB

lysate

Fig 1.

Loss of $\mathrm{T}$ cell IFN- $\gamma$ responses in $\mathrm{HIV}^{+}$individuals after long-term cryopreservation. PBMC from the same phlebotomy were frozen and tested for (a) $\mathrm{CD}^{+}$IFN- $\gamma$ and (b) $\mathrm{CD} 8^{+} \mathrm{IFN}-\gamma$ responses to SEB, HIV peptides, p55 protein, MN and CMV lysate after short-term $(<170$ days) and long-term (>300 days) storage by 3 or 8 -color intracellular cytokine staining. Individual subjects are represented by distinct symbols, with dashed lines representing PBMC from acute HIV infection and solid lines representing PBMC from chronic HIV infection. Subject symbols are consistent throughout the panels and figures. 

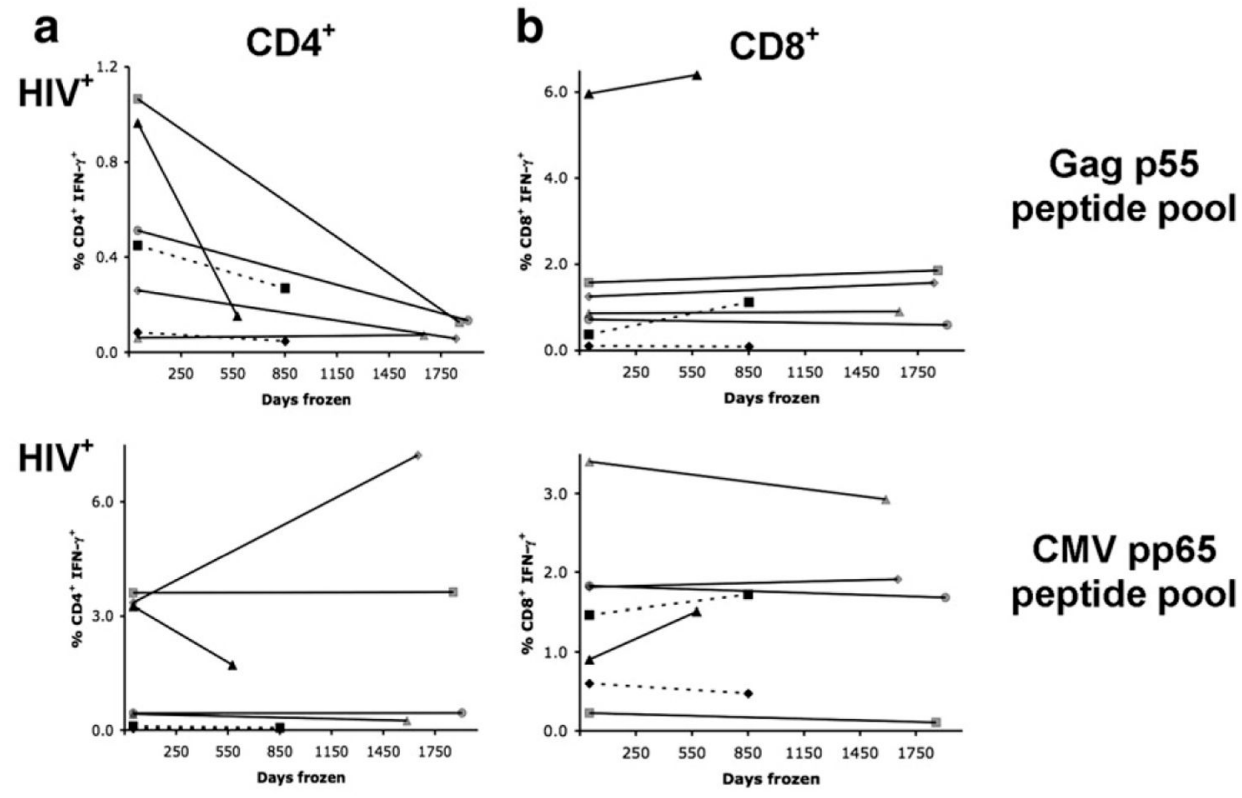

\section{CMV pp65 peptide pool}
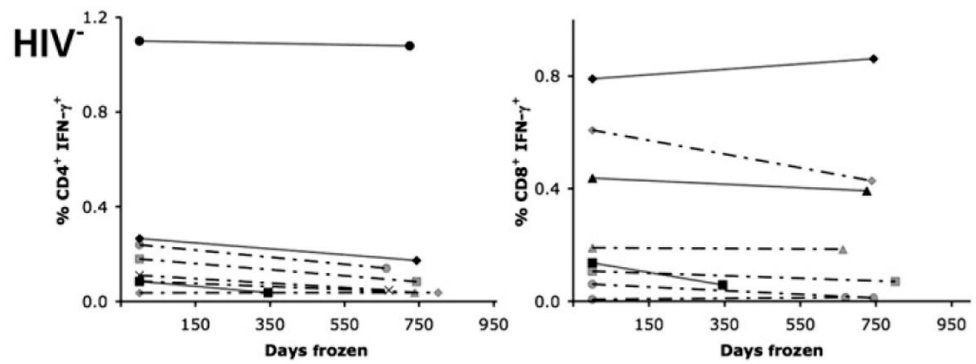

\section{CMV pp65 peptide pool}

Fig 2.

Confirmation of loss of $\mathrm{CD}^{+}{ }^{+} \mathrm{IFN}-\gamma$ responses in $\mathrm{HIV}^{+}$individuals after long-term cryopreservation. Fresh, whole blood was stimulated with CMV pp65 and Gag p55 peptide pools and (a) $\mathrm{CD}^{+} \mathrm{T}$ cell and (b) $\mathrm{CD}^{+} \mathrm{T}$ cell $\mathrm{IFN}-\gamma$ responses were measured by four-color intracellular cytokine staining. PBMC from the same phlebotomy were cryopreserved for long periods of time (345-1907 days) and stained with six-color intracellular cytokine staining at UCSF CIL. Individual subjects are represented by different symbols, with grey lines representing PBMC from $\mathrm{HIV}^{-}$individuals, dotted and dashed lines representing Towne CMV vaccine recipients, dotted lines representing acute HIV infection, solid lines representing PBMC from chronic HIV infection and solid lines with grey symbols representing individuals from a HIV STI cohort. Subject symbols are consistent throughout the panels. 

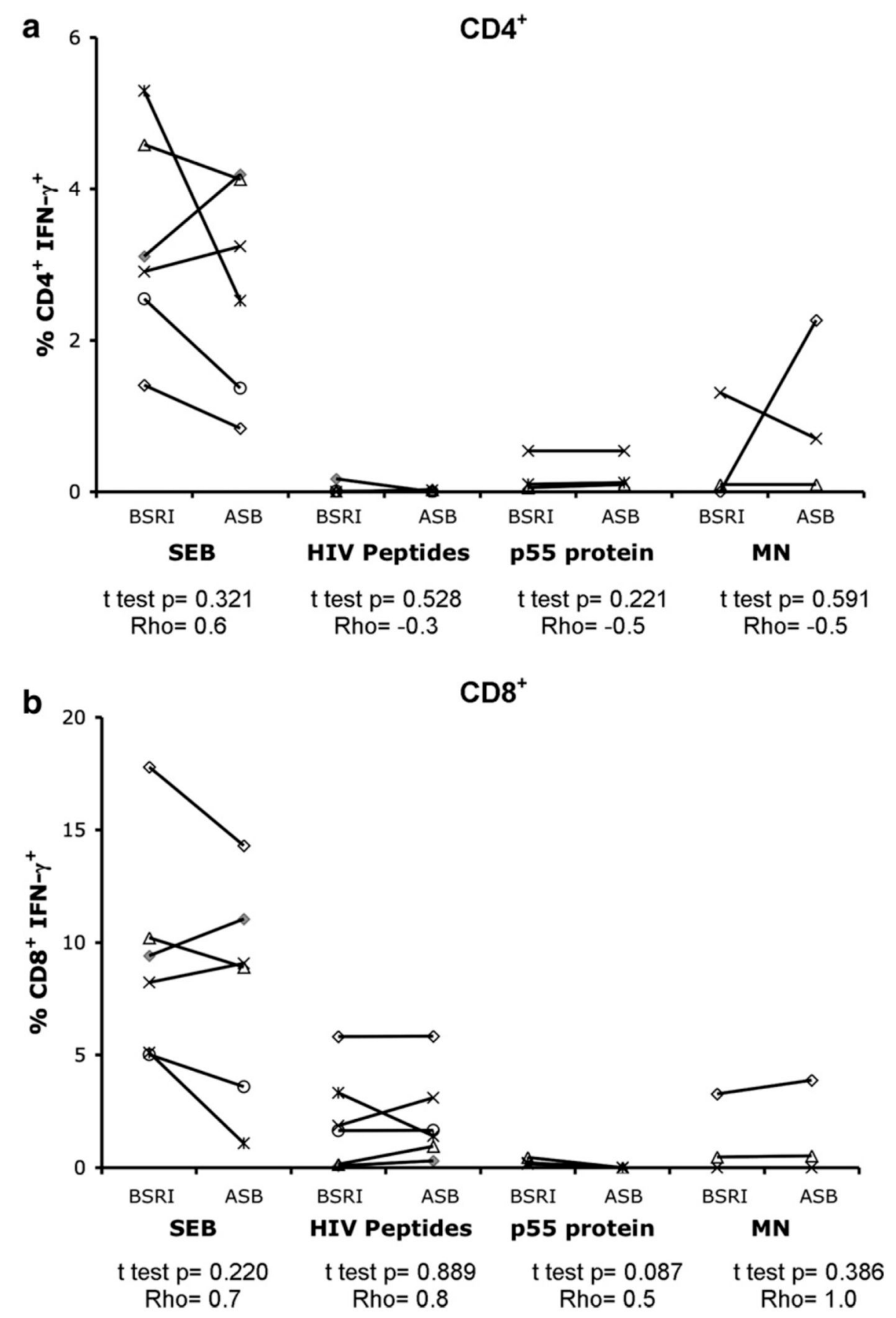

Fig 3.

Correlation of responses in PBMC frozen at two independent laboratories. Long-term cryopreserved PBMC (621-917 days frozen) from six individuals from the chronic HIV cohort (SCOPE) from the same phlebotomy processed at BSRI or at UCSF ASB were stimulated with SEB, HIV peptides, p55 protein or MN. CD4 ${ }^{+}$IFN- $\gamma$ (a) and $\mathrm{CD}^{+}$IFN- $\gamma$ (b) T cell responses were measured by three-color flow cytometry. Two-tailed, paired $t$ tests were performed, and Spearman's rank correlation coefficient (Rho) was calculated for BSRI processed versus ASB processed PBMC. 
a
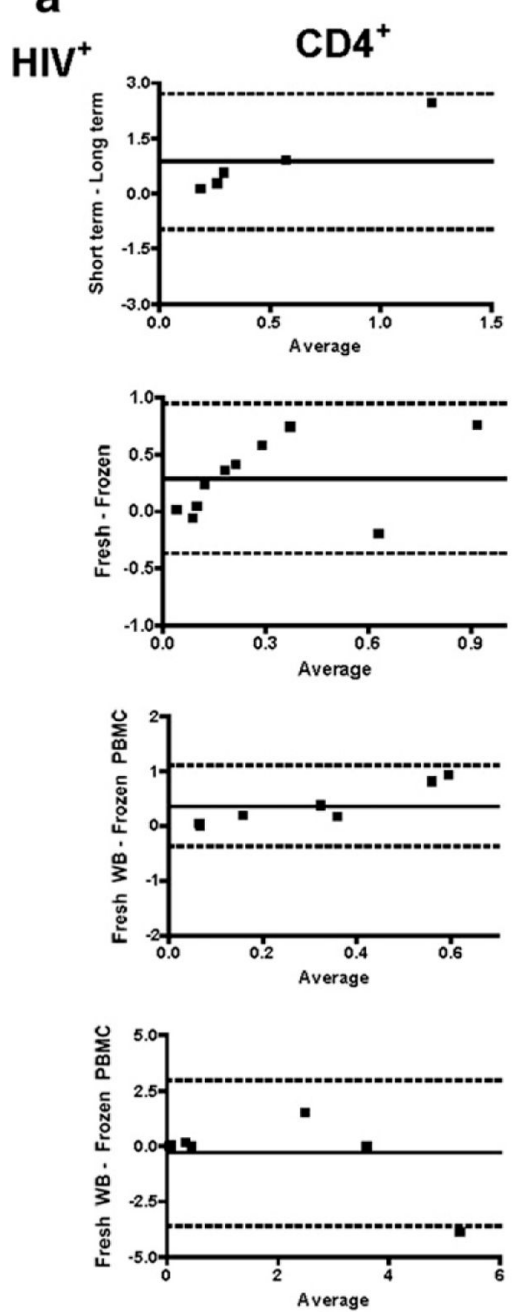

HIV

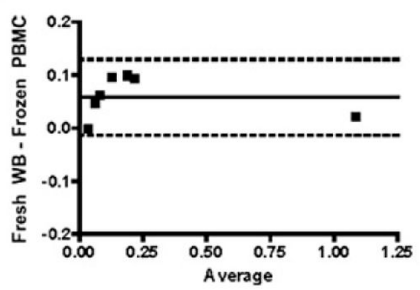

b
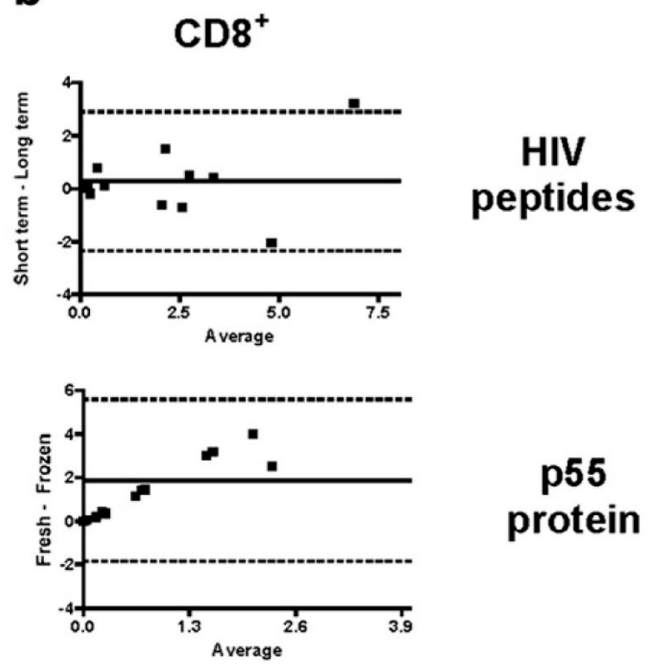

p55

protein

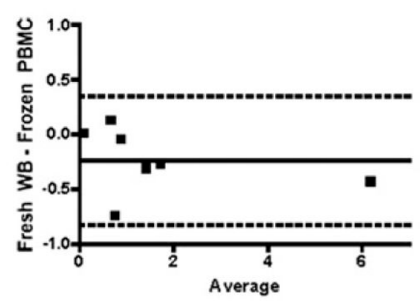

\section{Gag p55}

peptide pool

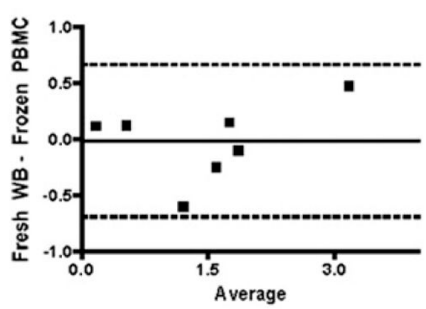

CMV pp65

peptide pool

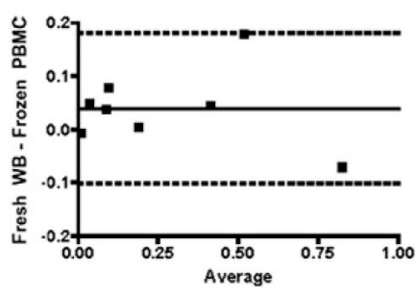

\section{CMV pp65} peptide pool

Fig 4.

Bland-Altman analysis of T cell IFN- $\gamma$ responses. Bland-Altman plots of fresh or short-term cryopreserved responses minus long-term cryopreserved responses vs. the average response are shown for (a) $\mathrm{CD}^{+} \mathrm{T}$ cell IFN- $\gamma$ and (b) $\mathrm{CD} 8^{+} \mathrm{T}$ cell IFN- $\gamma$ responses to HIV peptides, p55 protein, Gag p55 peptide pool and CMV pp65 peptide pool in $\mathrm{HIV}^{+}$and $\mathrm{HIV}^{-}$individuals. The mean bias was plotted with a solid line and $95 \%$ limits of agreement with dashed lines. 
a

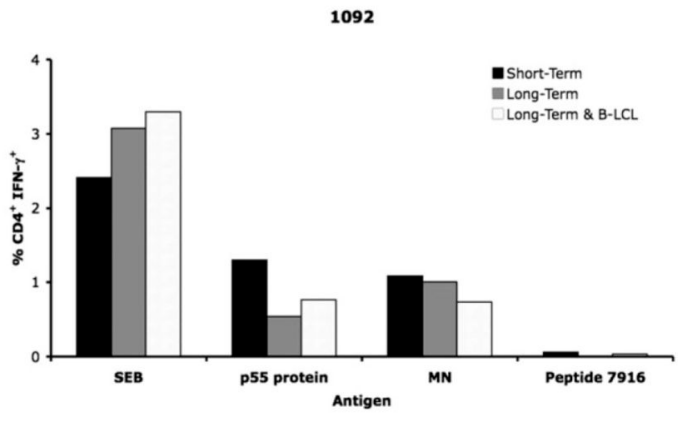

3169

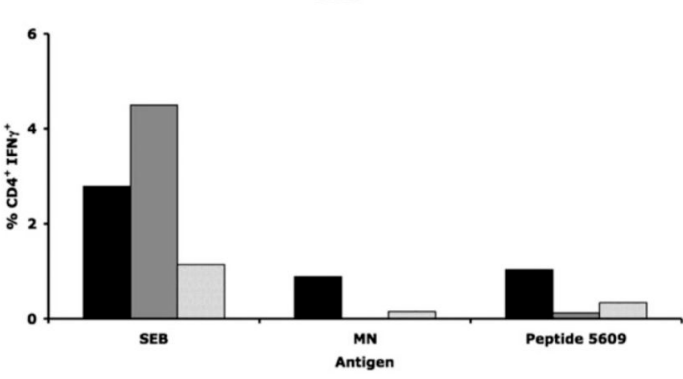

3040
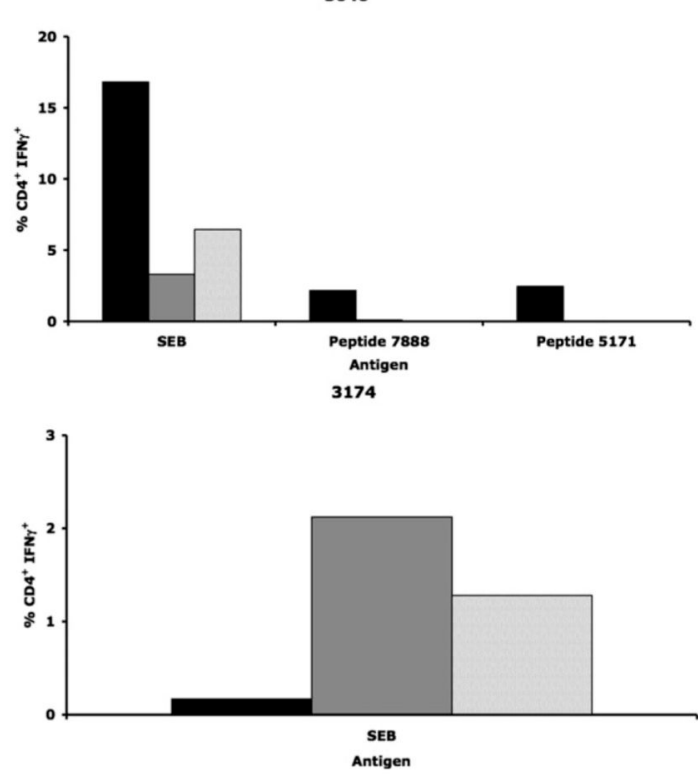

b $\mathrm{CDB}^{+}$

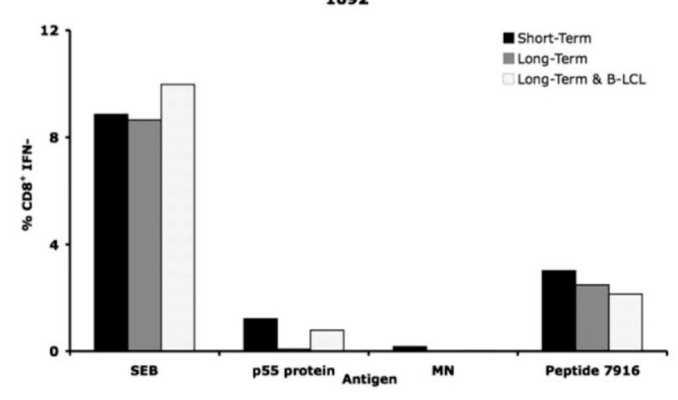

3169
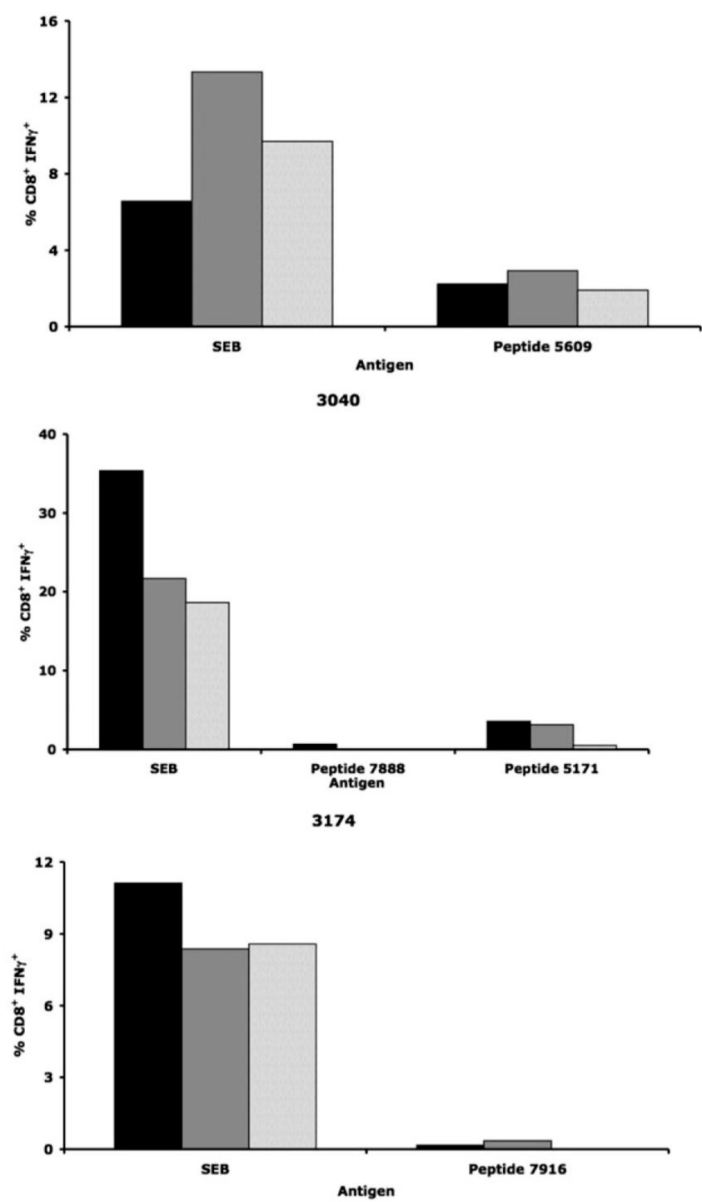

Fig 5.

Addition of autologous APC to long-term cryopreserved PBMC. Autologous B-LCL prepulsed with SEB, p55 protein, MN or individual HIV peptides were added at a 1:1 ratio to long-term cryopreserved PBMC (634-939 days frozen; hatched bars) and (a) $\mathrm{CD}^{+}{ }^{+}$or (b) $\mathrm{CD}^{+} \mathrm{T}$ cell IFN-- $\gamma$ responses were compared to those measured in short-term cryopreserved PBMC (black bars) or in long-term cryopreserved PBMC stimulated without autologous BLCL (grey bars). The data shown are from four individuals tested from a cohort of individuals with chronic HIV infection. 

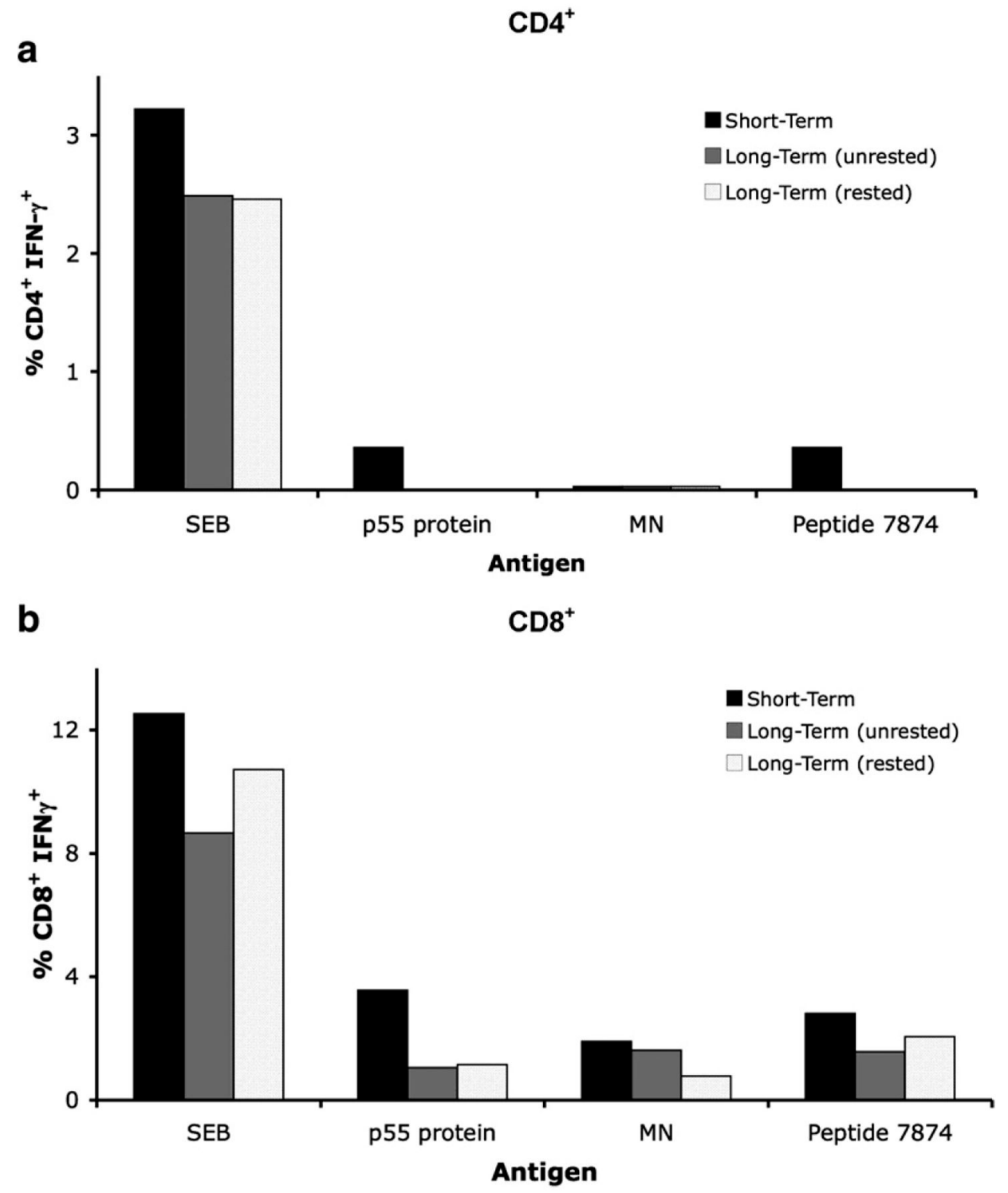

Fig 6.

T cell IFN- $\gamma$ responses not restored by overnight resting. Long-term cryopreserved PBMC (546-923 days frozen) were rested overnight (hatched bars) or stimulated directly after thawing (grey bars) with SEB, p55 protein, MN or HIV peptide 7874 (within Gag p17) and stained for intracellular IFN- $\gamma$ expression in (a) $\mathrm{CD}^{+}$and (b) $\mathrm{CD} 8^{+} \mathrm{T}$ cells using the 3 -color panel.

Responses measured in the short-term (unrested) cryopreserved PBMC are shown by the black bars. The data shown are representative of 1 out of 10 individuals tested from a cohort of individuals with chronic HIV infection. 
a

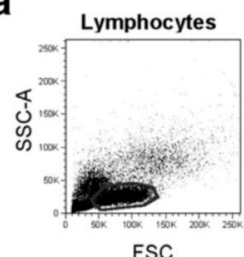

b

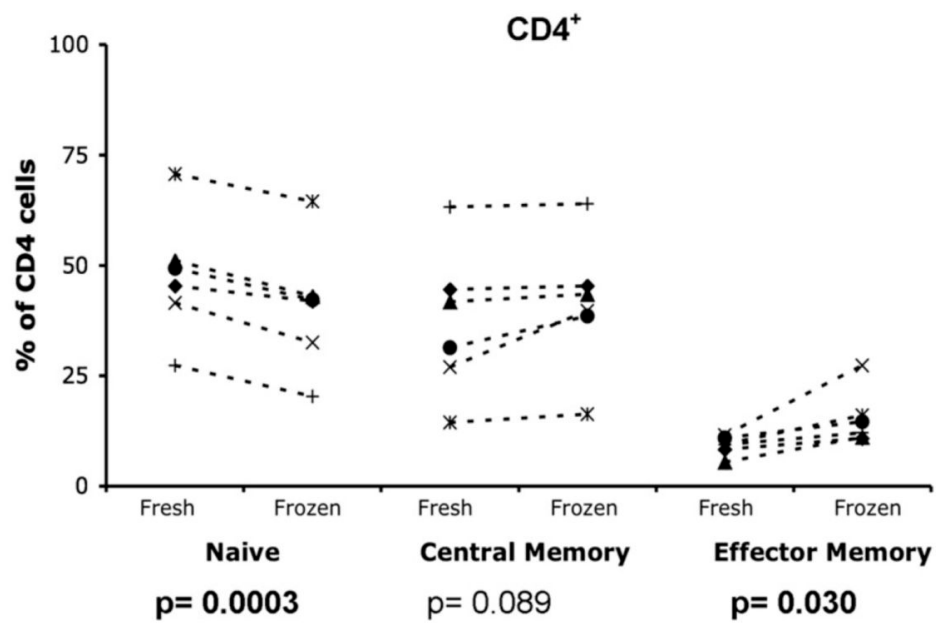

d

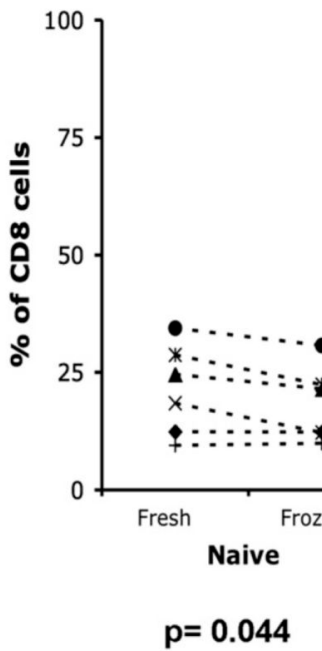

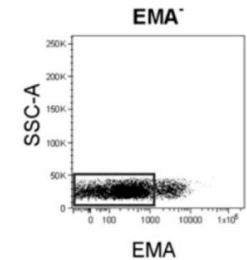

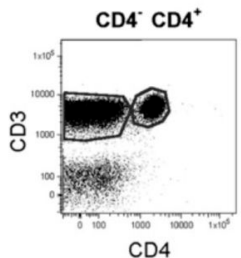

$\mathrm{CD} 4$
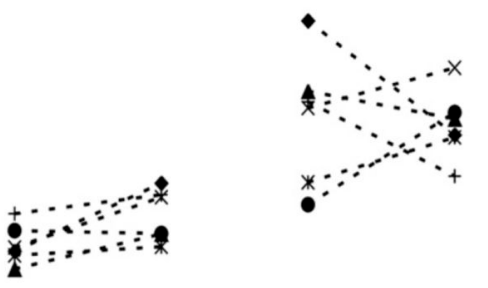
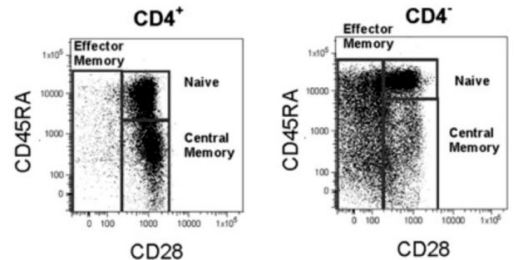

C
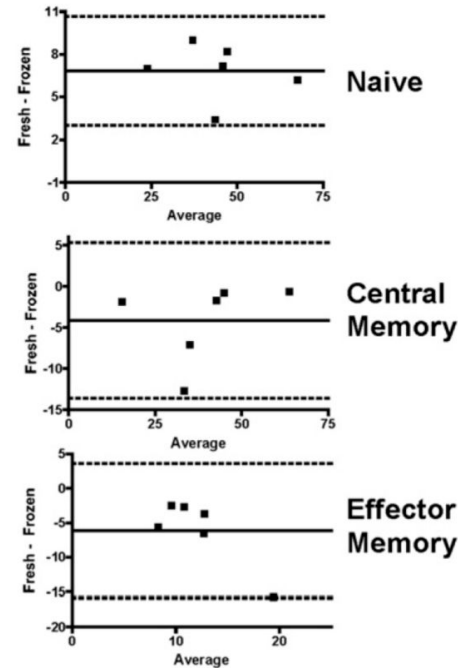

e
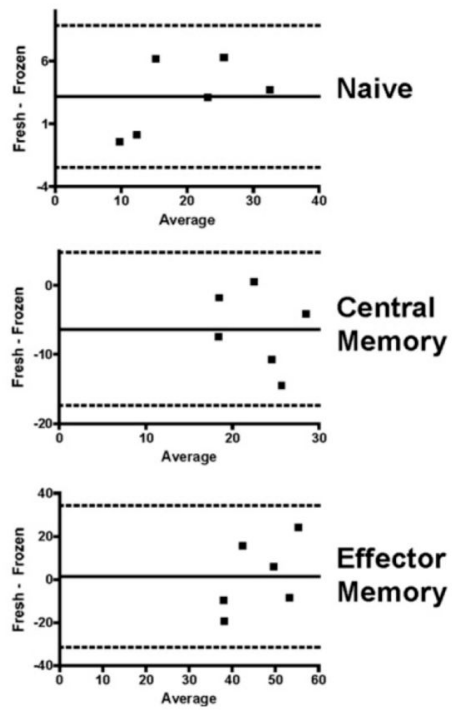

Fig 7.

Decreased naïve cells after long-term cryopreservation. (a) Naïve cells are defined as CD45RA ${ }^{+} \mathrm{CD}_{28}{ }^{+}$; central memory cells as CD45RA ${ }^{-}$CD28 $8^{+}$and effector memory cells as

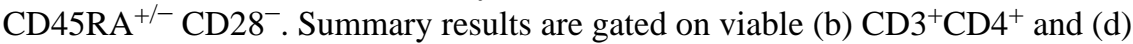
$\mathrm{CD} 3^{+} \mathrm{CD} 4^{-1}$ unstimulated PBMC from fresh and long-term cryopreserved ( $>300$ days) samples from the same phlebotomy. Two-tailed, paired $t$ tests were performed with significant $p$ values highlighted in bold. Bland-Altman plots showing the difference of fresh PBMC (naïve, central memory or effector memory) minus long-term cryopreserved PBMC (naïve, central memory or effector memory) vs. the average are shown for (c) $\mathrm{CD}^{+}$and (e) $\mathrm{CD}^{+} \mathrm{T}^{-}$ 
cell phenotypes. The bias is plotted with a solid line and 95\% limits of agreement with dotted lines. 
a

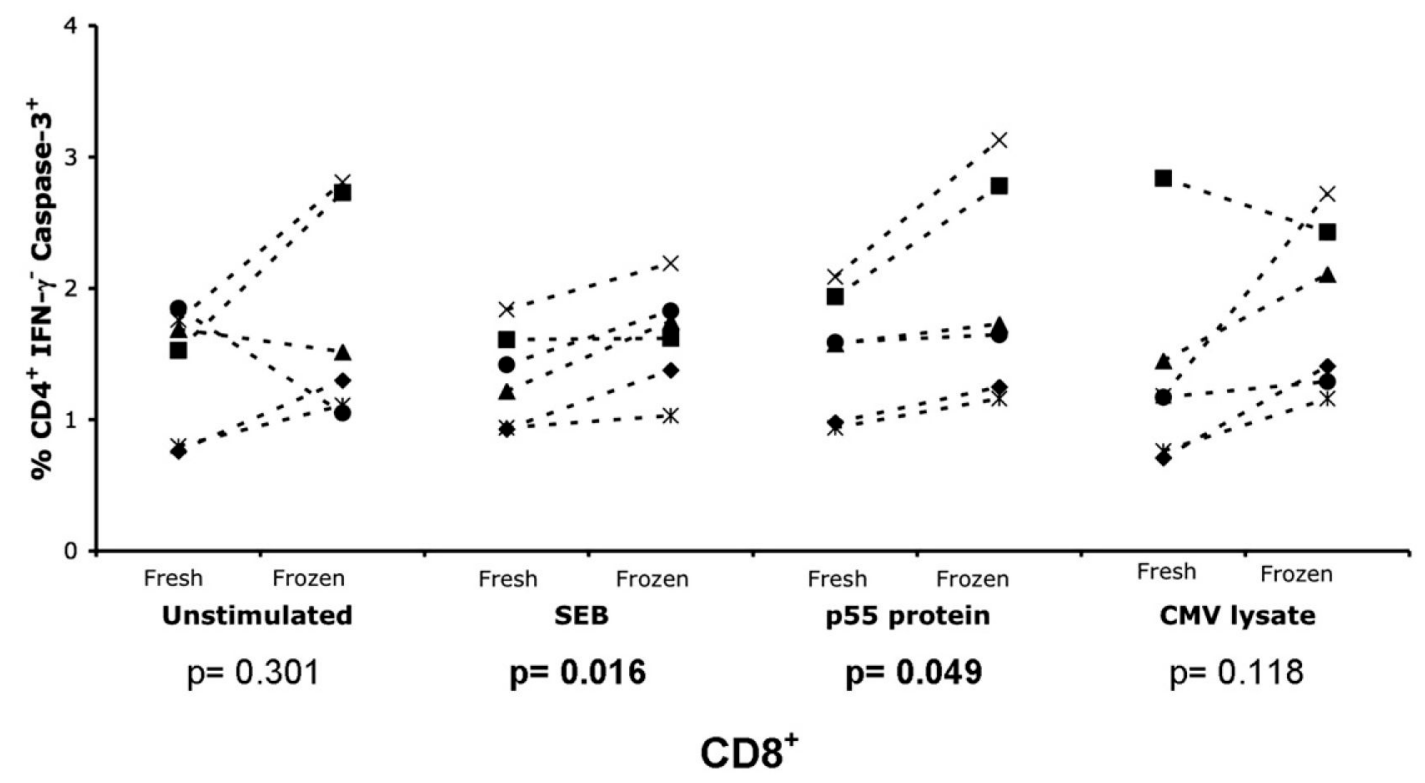

b

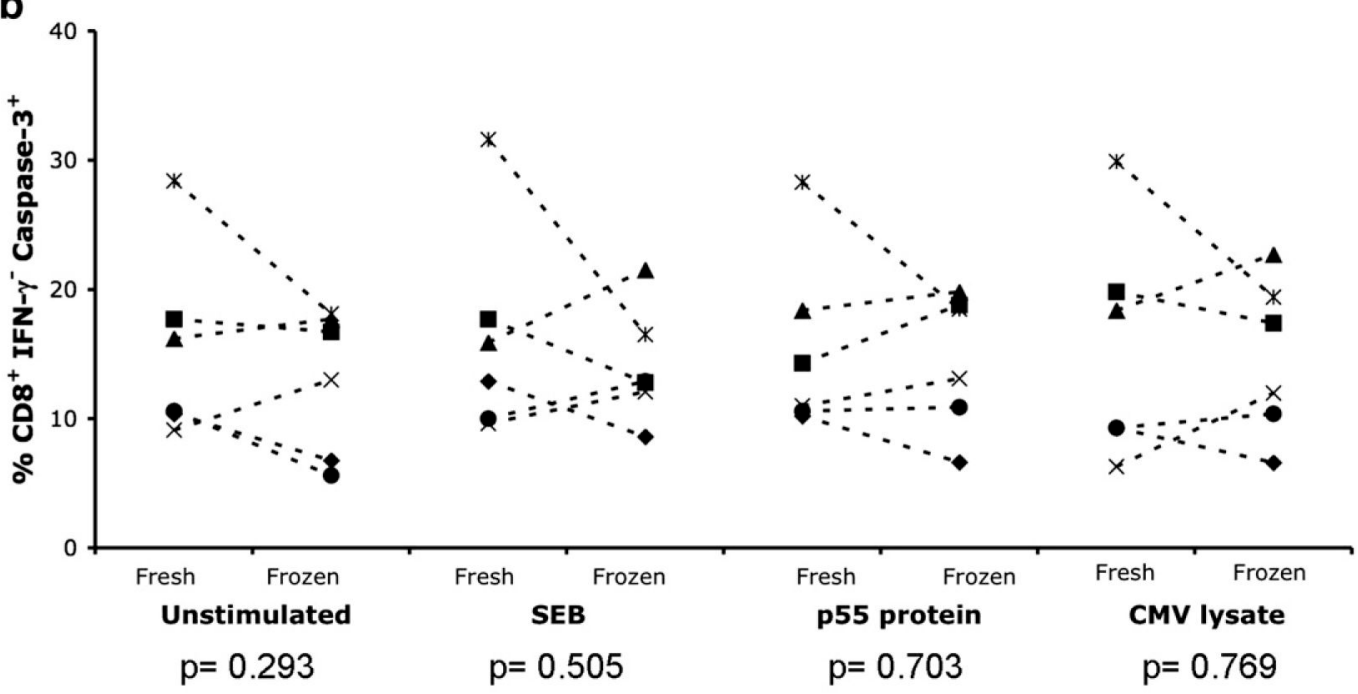

Fig 8.

Increased apoptosis after long-term cryopreservation. Intracellular caspase- 3 staining of (a) CD4 ${ }^{+}$IFN- $\gamma^{-}$and (b) $\mathrm{CD}^{+}$IFN- $\gamma^{-}$T cells from freshly isolated and long-term cryopreserved (>300 days) PBMC following no stimulation or overnight stimulation with SEB, p55 protein, or CMV lysate is shown for individuals from the acute HIV infection cohort. Two-tailed, paired $t$ tests were performed, with significant $p$ values highlighted in bold. 


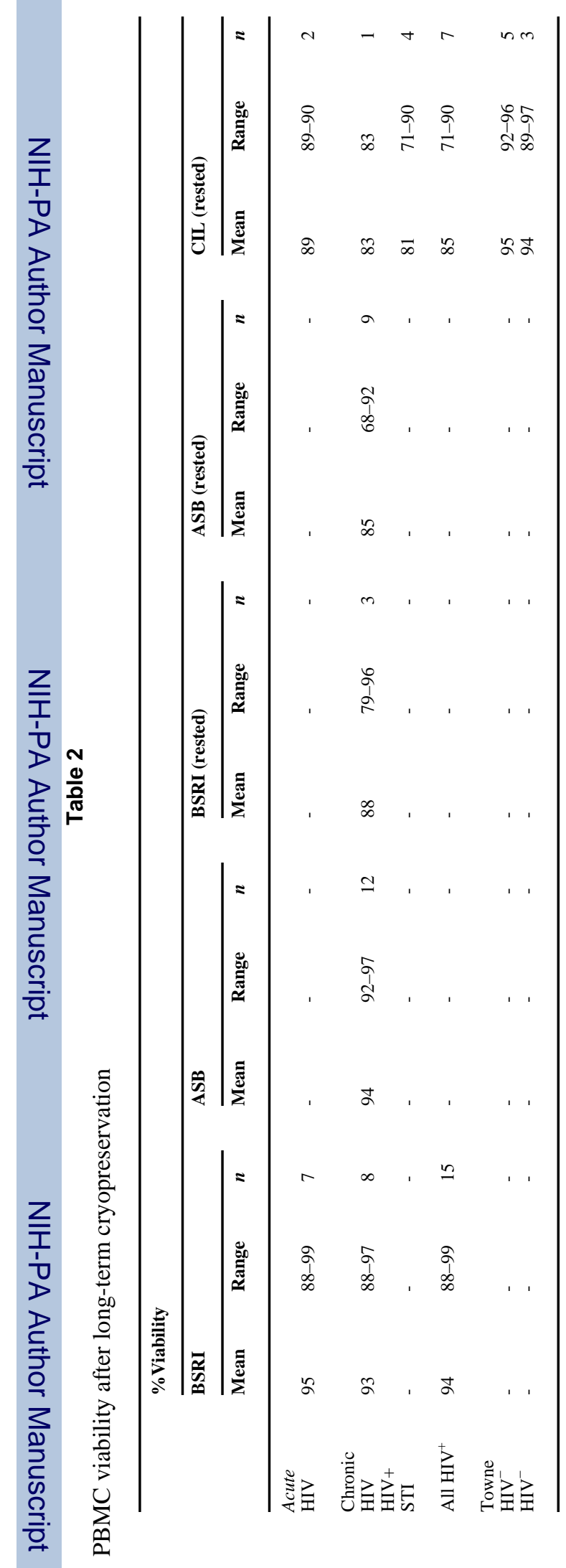


Owen et al.

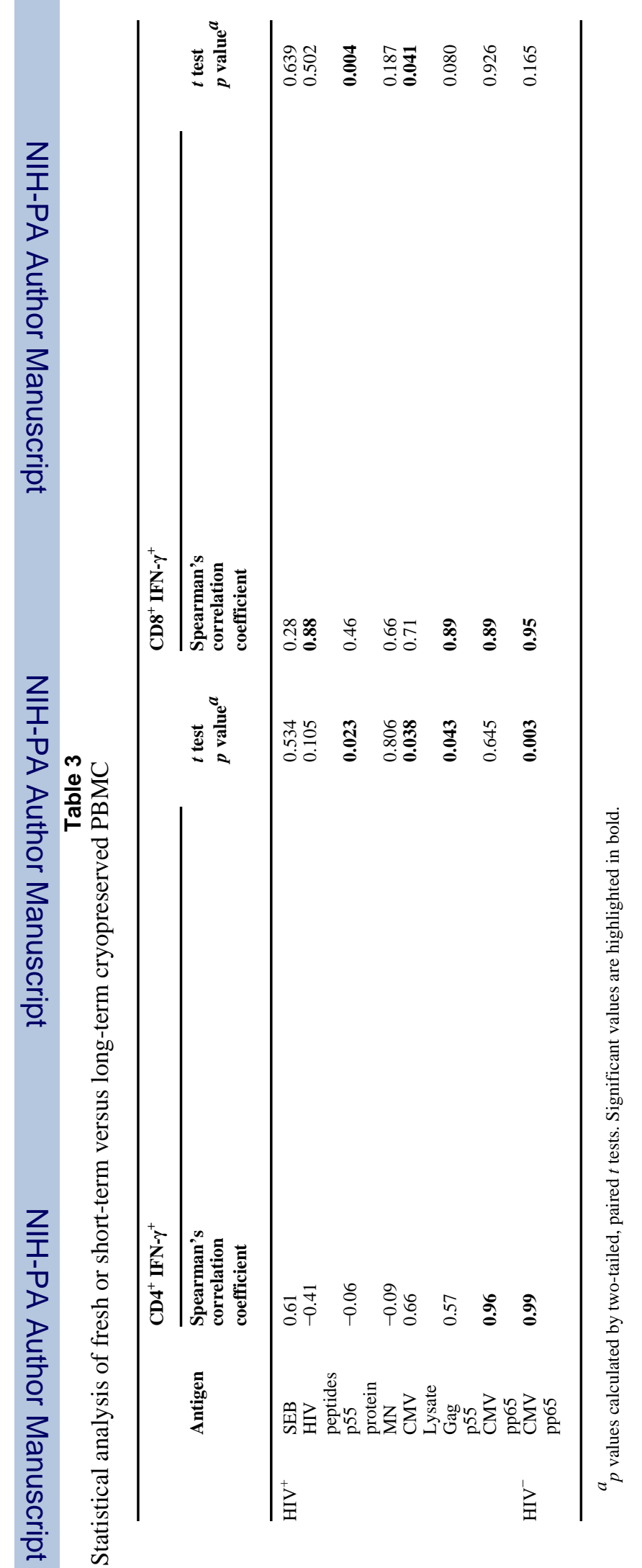




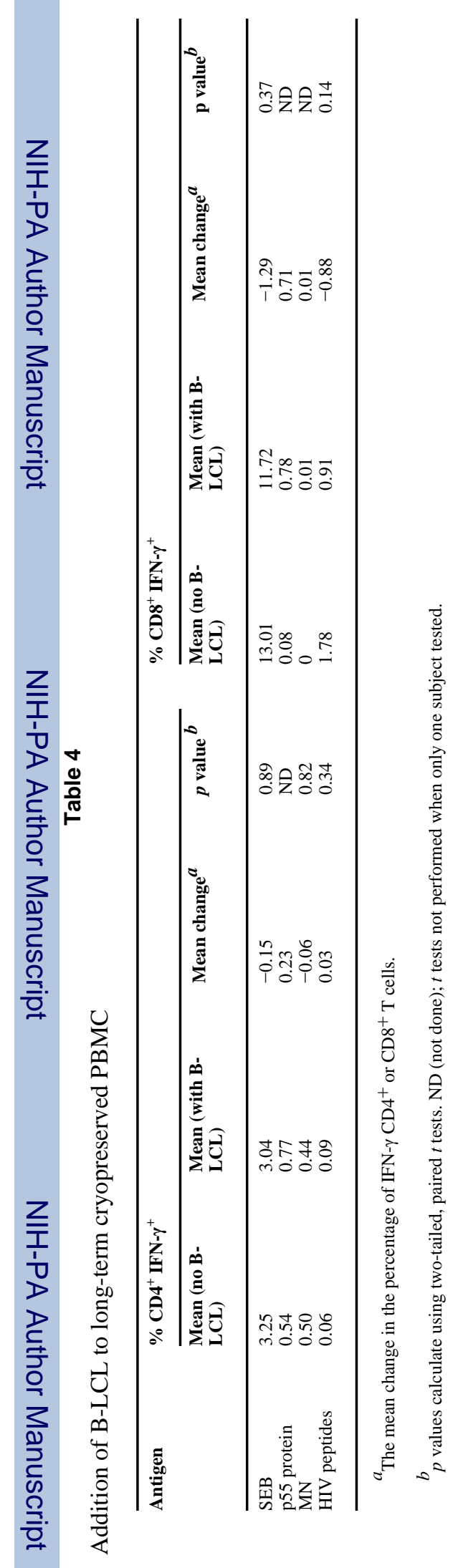




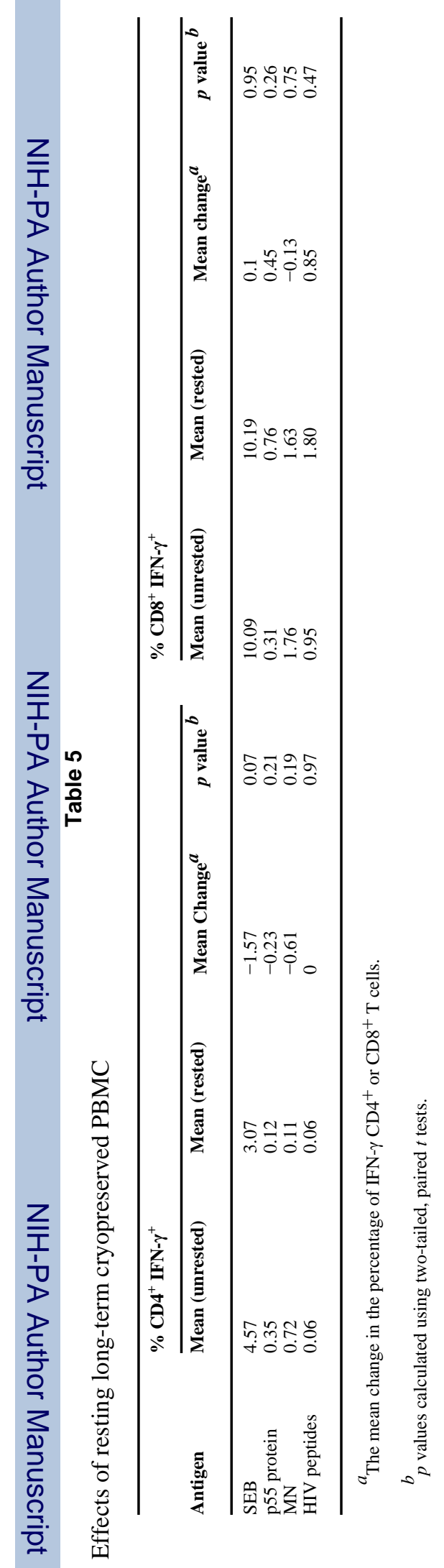

